Algal Research

April 2018, Volume 31 Pages 395-405

http://dx.doi.org/10.1016/i.algal.2018.02.023

http://archimer.ifremer.fr/doc/00429/54036/

(c) 2018 Elsevier B.V. All rights reserved.

\title{
First insight on interactions between bacteria and the marine diatom Haslea ostrearia : Algal growth and metabolomic fingerprinting
}

\author{
Lépinay Alexandra ${ }^{1,2}$, Turpin Vincent ${ }^{1}$, Mondeguer Florence ${ }^{4}$, Grandet-Marchant Quentin ${ }^{1}$, \\ Capiaux Hervé ${ }^{2,3}$, Baron Regis ${ }^{5}$, Lebeau Thierry ${ }^{2,{ }^{*}}$
}

${ }^{1}$ Université de Nantes, 2 rue de la Houssinière, BP, 92208, 44322 Nantes Cedex, France

${ }^{2}$ CNRS, Université de Nantes, 2 rue de la Houssinière, BP, 92208, 44322 Nantes Cedex, France

${ }^{3}$ Plateforme d'Analyse Moléculaire Biodiversité-Environnement, IUT Génie Biologique, 85035 La Roche sur Yon, France

${ }^{4}$ IFREMER, Laboratoire Phycotoxines, rue de l'ile d'Yeu, 44311 Nantes 03, France

${ }^{5}$ IFREMER, Unité Biotechnologie et Ressources Marines, rue de l'ile d'Yeu, 44311 Nantes 03, France

*Corresponding author : Thierry Lebeau, email address : thierry.lebeau@univ-nantes.fr

\begin{abstract}
:
A first insight on the interactions between bacteria isolated from monospecific cultures of the marine diatom Haslea ostrearia and this microalgae is described in this work. From 28 bacterial isolates, the maximal growth rate and the maximal cell concentration were on average $58 \%$ and $27 \%$ higher (max. $67 \%$ for isolate B22). Isolates B5, B10 (both Saccharospirillum sp.) and B22 (Rhodobacter sp.) were the most efficient. The geographical origin of $H$. ostrearia from which bacteria were isolated had no impact on the algal growth performances, and a given bacterial isolate led to the same algal growth irrespective of the geographical origin of $\mathrm{H}$. ostrearia. To explain the results obtained, a comprehensive integrative strategy was conducted that analyzed the variations in the thousands of metabolites present in our culture extracts. Beyond a holistic view in which all organic substances of natural origin derived from the metabolism of a living organism were analyzed, we focussed on metabolites specific to each partner of the bacteria- $H$. ostrearia co-cultures, and relating to a particular biological function. To this end, a high throughput analytical technique, mass spectrometry was used, along with uni- and multivariate association statistical methods. Metabolic fingerprinting (untargeted approach) enabled compounds specific to each association to be identified, especially those concerning the positive bacterial effect on the growth of $H$. ostrearia.
\end{abstract}




\section{Highlights}

- Haslea ostrearia and bacteria isolated from this marine diatom were co-cultivated. Saccharospirillum sp. and Rhodobacter sp. increased the most the algal growth. The maximal cell concentration of $H$. ostrearia was on average 27\% (max. 67\%) higher. A given bacteria led to the same algal growth irrespective of the $H$. ostrearia origin. Metabolic fingerprinting enabled compounds specific to each association.

Keywords : Bacterial selection, Plant-growth-promoting bacteria, Phycosphere, Metabolomics 


\section{Introduction}

Microalgae are recognized for their high productivity, for their ability to grow in wastewater, non-arable land, etc. under well controlled conditions in photobioreactors as well as in open ponds, and with a wide commercial applications (fuel industries, wastewater treatment, and also high value-added molecules) as reviewed for diatoms by Lebeau and Robert [1]. Although the habitat of phytoplankton-associated bacteria has long been depicted by the concept of the "phycosphere", i.e., the area around algal cells where bacteria feed on the extracellular products of the algae [2], which is still a matter of research [3-5]. Indeed, "algae have received much attention for industrial exploitation but their interaction with bacteria is often considered as a contamination during commercialization", as reported by Ramanan et al. [6], probably because research in bioengineering considers that axenic microalgae, i.e., a single population, is easier to control than several microbial populations and/or it is less expensive to recover the final product (algal biomass, molecules). Yet potential applications of bacteria-algae cocultures exist in aquaculture [7]. The nature of the bacterial chemical compounds involved in the supplementary algal growth (indole-3-acetic acid. Vitamin $\mathrm{B}_{12}$, siderophores, antibiotics: [8], [6]) is central in the bacteria-microalgae interactions but have been poorly studied to date in comparison with higher plant-microbe interactions. Cultureindependent methods like metagenomics and metabolomics can be employed to investigate the complexity of such interactions [9]. Some bacteria-microalgae interactions deal with diatom species (see review by Amin et al. [10]), including Guinardia delicatula, Pseudonitizschia pugens, Thalassiosira rotula, Skeletonema costatum [11], Ditylum sp., Thalassiosira sp., Asterionella sp., Chaetoceros sp., Leptocylindrus sp., Coscinodiscus sp. [12], Pseudo-nitzschia multiseries [13] and Nitzschia microcephala [14]. It has been shown 
that some bacteria (or yeasts) may increase the biomass of various microalgal genera including diatoms [15-21].

As yet, nothing is known about the interactions between the marine diatom Haslea ostrearia and its surrounding bacteria in the natural environment. This microalga is a cosmopolitan diatom species commonly found on the French Atlantic coast, especially in oyster ponds of Marennes-Oléron Bay and Bourgneuf Bay. It became a subject of investigation since 1927 [22] due to its water-soluble, blue-green pigment, called marennine, which is responsible for the greening of oysters and because the conditions of its synthesis, as the result of a peculiar biological cycle (successively planktonic and benthic periods) as described by Robert et al. [23], was specific of this blue diatom (for more details, see the review of Gastineau et al. [24]). It is noteworthy that some other marennine applications have been reported in this overview: i) antibacterial, anticoagulant and antiviral activities; ii) antioxidant activity, and iii) antitumor and antiproliferative effects of the aqueous extract from $H$. ostrearia on solid tumors (lung and kidney carcinoma and melanoma cell line molecules) and whose photoprotective role of this pigment can act as complexing ligands leading to decreased bioavailability of metals [25-27].

Yet, nothing was known about the bacteria surrounding $H$. ostrearia until our recently published work regarding the analysis of the bacterial structure of the $H$. ostrearia phycosphere [28]. This work notably showed that the level of similarity between the bacteria recovered from the microalgal biofilm and the suspended bacteria did not exceed $10 \%$. On the contrary, similarities between the bacterial community structures in biofilms were above $90 \%$ regardless of the geographical origin of the $H$. ostrearia isolates. This finding shows that the bacteria of the phycosphere are specific to $H$. ostrearia without yet supplying any data on the potential interactions. 
In the continuity to this preliminary study, the present work aimed to test i) the impact of bacteria isolated from monospecific cultures of $H$. ostrearia on the growth of this microalga and ii) to provide an insight into these interactions based on the analysis of metabolites resulting from the bacteria- $H$. ostrearia interactions. Firstly bacteria were isolated from either the water column (free cells) or biofilms surrounding H. ostrearia cells and tested in coculture with an $H$. ostrearia isolate. Thereafter, some bacteria co-cultivated with this algal isolate were also co-cultivated with another algal isolate harboring the most distinct bacterial structure in its natural environment to test the specificity of the bacteria- $H$. ostrearia interactions. Eventually, to assess the overall metabolic profile of the extracellular compounds synthesized by both $H$. ostrearia isolates associated with some of the isolated bacteria, metabolic fingerprinting (untargeted approach) was performed, along with the identification of some compounds, by liquid chromatography high resolution mass spectrometry (LCHRMS). Then an attempt was made to relate the different profiles obtained with the ability (or not) of bacteria to stimulate microalgal growth.

\section{Material and methods}

2.1. Isolation of bacteria from Haslea ostrearia cultures

Bacteria were isolated from Haslea ostrearia isolates cultivated in ES 1/3 medium [29] in laboratory conditions over a 3-month period. These microalgal isolates were recovered from four sites on the French Atlantic coast: Bouin $\left(46.96^{\circ} \mathrm{N} ; 2.04^{\circ} \mathrm{W}\right)$, La Barre-de-Monts (46.90 $\left.\mathrm{N} ; 2.11^{\circ} \mathrm{W}\right)$, Isle de Ré (46.22 N; $\left.1.45^{\circ} \mathrm{W}\right)$, and La Tremblade $\left(45.80 \mathrm{~N} ; 1.15^{\circ} \mathrm{W}\right)$ [28] and were non-axenic, i.e., they harbored autochthonous bacteria (H. ostrearia only axenic for metabolomic analysis: see section 2.2.). 
Suspended bacterial cells in the culture medium and cells trapped in the microalgal biofilm surrounding H. ostrearia cells (named hereafter "free cells" and "biofilm cells", respectively) were isolated. For "free cells", $100 \mathrm{~mL}$ of the H. ostrearia culture in the exponential growth stage was carefully collected to avoid any contact with the algal biofilm (wholly attached at the bottom of the Erlenmeyer flasks at this stage), filtered at $4 \mu \mathrm{m}$ to eliminate suspended microalgae and centrifuged (SIGMA 3K30 Fisher Bioblock Scientific, 6000 g, 10 min, room temperature). The bacterial pellet was re-suspended in fresh ES 1/3 medium from which serial dilutions in $\mathrm{NaCl} 28 \mathrm{~g} \mathrm{~L}^{-1}$ were made and plated on Petri dishes filled with Marine Agar (Difco ${ }^{\mathrm{TM}}$ Marine Broth 2216 supplemented with agar $15 \mathrm{~g} \mathrm{~L}^{-1}$ ). For the "biofilm cells", all the culture medium was removed. Thirty milliliters of fresh ES 1/3 medium was added and the biofilm was set in suspension (by the mechanical action of a sterile bar magnet) from which serial dilutions and plating were carried out as mentioned above for free cells.

After a 4-week incubation at $16^{\circ} \mathrm{C}$ and under $120 \mu \mathrm{mol}$ photon $\mathrm{m}^{-2} \mathrm{~s}^{-1}$ and a $14: 10 \mathrm{~h}$ (light: dark) regime in Marine Agar, different bacterial morphotypes were selected (color, appearance). Each bacterial isolate was re-suspended in $\mathrm{NaCl} 28 \mathrm{~g} \mathrm{~L}^{-1}$ and purified by streaking 3 times on Petri dishes filled with Marine Agar. Next, the isolates were cultured in liquid Marine Broth (Difco ${ }^{\mathrm{TM}}$ Marine Broth 2216) and stored at $-80^{\circ} \mathrm{C}$ after glycerol addition (0.3 mL glycerol for $1.2 \mathrm{~mL}$ bacterial culture). Before each bacteria-H. ostrearia co-culture, isolated bacteria were thawed and cultivated in liquid Marine Broth for $72 \mathrm{~h}$ at $16^{\circ} \mathrm{C}$. In addition to the bacterial collection, Azospirillum brasilense was used as a control bacterium, known for its ability to stimulate the growth of terrestrial plants and microalgae [30]. It was cultivated, stored and thawed in the same conditions as all isolated bacteria. 
Only H. ostrearia isolates from La Barre-de-Monts (Ho-BM) and Isle de Ré (Ho-R) were used for axenization and used for experiments dedicated to the metabolomic fingerprinting. The protocol was described extensively in [28]. Briefly, non-axenic cultures of $H$. ostrearia in the exponential growth stage were treated twice with an antibiotic antimycotic solution (10,000 units of penicillin, $10 \mathrm{mg}$ of streptomycin and $25 \mu \mathrm{g} \mathrm{mL} \mathrm{L}^{-1}$ of amphotericin $\mathrm{B}$, BioReagent, A5955 SIGMA) for 7 days. After the second treatment, cultures were called "axenic" if no turbidity was observed after 10 days of culture in obscurity on two specific marine bacterial liquid medium (FAG and FG tests).

\subsection{Bacteria-H. ostrearia co-cultures}

Experiment 1: A non-axenic culture of $H$. ostrearia from La-Barre-de-Monts (Ho-BM) was co-cultivated with each of the 28 marine bacteria isolated from the H. ostrearia isolates of the four localities and with Azospirillum brasilense. All the co-cultures were compared to a control, i.e., a non-axenic culture of $H$. ostrearia without addition of bacterial isolates (called a "monoculture"). H. ostrearia cells from a 250-mL culture in the exponential growth stage were inoculated in a 24-well plate (CytoOne, StarLab) at $3.10^{3}$ cells $\mathrm{mL}^{-1}$. Bacterial strains were pre-cultivated in Marine Broth for $72 \mathrm{~h}$ at $16^{\circ} \mathrm{C}$, then washed twice with ES 1/3 medium, harvested by centrifugation at $5000 \mathrm{~g}$ for $6 \mathrm{~min}$ at $16^{\circ} \mathrm{C}$ (SIGMA 3K30 Fisher Bioblock Scientific) and inoculated in each well at $3.10^{6}$ cells $\mathrm{mL}^{-1}$. The co-culture experiments were performed in triplicate. The bacteria-microalgae co-cultures were incubated in a culture chamber equipped with LED panels at $16^{\circ} \mathrm{C}$ under $120 \mu \mathrm{mol}$ photon $\mathrm{m}^{2} \mathrm{~s}^{-1}$ and a $14: 10 \mathrm{~h}$ (light:dark) regime (i.e., conditions adapted to $H$. ostrearia). 
Experiment 2: Bacterial isolates B5, B10, B26 and B36 selected based on the results of experiment 1 and $A$. brasilense were co-cultivated with $H$. ostrearia isolates from two different geographical origins: Isle de Ré (Ho-R) and La-Barre-de-Monts (Ho-BM). All the co-culture conditions were the same as for Experiment 1 and were compared to non-axenic monocultures of Ho-R and Ho-BM used as controls.

\subsection{Analysis}

\subsubsection{Microalgal cell counting}

Algal growth was monitored by measuring the fluorescence of chlorophyll $a$ in each well (wavelength: excitation $440 \mathrm{~nm}$, emission $680 \mathrm{~nm}$, BMG LabTech) twice a day for ten days. Parameters and specifications were as follows: WellScan mode, matrices $4 \times 4$, diameter 15 , 30 flashes per well, $0.1 \mathrm{sec}$ to wait in between each well. To avoid any contamination during the measurements, an adhesive film was used to cover the plate. The microalgal density was determined as a function of the fluorescence intensity based on a calibration curve (for each counting). Monocultures were realized at the same time as the co-cultures and in the same conditions (temperature, medium, light intensity) to be able to take into account the potential changes of the chlorophyll content of the cells. Moreover, bacterial interference was taken into account: i) bacterial densities in the range $5 \times 10^{7}-9.10^{8}$ cells $\mathrm{mL}^{-1}$ were added to two microalgal suspensions set at $3 \times 10^{3}$ cells $\mathrm{mL}^{-1}$ and $3 \times 10^{4}$ cells $\mathrm{mL}^{-1}$; ii) a fixed bacterial density, i.e., 10 times that used for the inoculation of plate wells, was added to the microalgal suspensions at a density ranging from $3 \times 10^{3}$ to $9 \times 10^{4}$ cells $\mathrm{mL}^{-1}$. 


\subsubsection{Non-targeted metabolomic analysis}

Currently, a major challenge in the field of metabolomics is interpreting untargeted profiling results in the context of biological studies. LC/MS-based untargeted metabolomics is now an established technology that is routinely used to study biological systems. Here ultra-high performance liquid chromatography quadrupole/time of flight-mass spectrometry (UHPLCQTOF-MS): see below for details) was used with multivariate statistical analysis to detect the differences in compound patterns between Ho-R co-cultures with bacteria B10 and B26, and Ho-BM co-cultures with bacteria B10 and A. brasilense. Axenic and non-axenic H. ostrearia cultures were compared. The different $H$. ostrearia culture extracts were profiled to find out if this unbiased approach, without preconceptions, confirmed the biological hypothesis put forward, i.e., highlighting growth-stimulating compounds specific to a microalgal-bacterial association.

Sample preparation: $200 \mu \mathrm{L}$ of the supernatant of a 6-day H. ostrearia culture (in the exponential growth stage) was collected, filtered at $0.20 \mu \mathrm{m}$ (PTFE membrane filters, Interchim) and frozen at $-80^{\circ} \mathrm{C}$ prior to fingerprint acquisition. Analyses were performed on thawed samples by UHPLC-QTOF-MS, implementing a non-targeted analytical strategy [31] to detect small soluble extracellular compounds produced by the bacteria and $H$. ostrearia recovered from the culture medium. The experimental design was carried out on the basis of 24 complex matrices $(n=3)$ equivalent aliquots $(5 \mu \mathrm{L})$ of each sample from the supernatant of $H$. ostrearia cultures, a simple matrix (culture medium, $\mathrm{n}=3$ ) serving as a control, and a certified reference materials of seven equimolar concentrations phycotoxins [32], including okadaic acid (OA), dinophysistoxin-1 (DTX1), yessotoxin (YTX), azaspiracid-1 (AZA1), 13desmethyl spirolide C (desMeC), gymnodimine (GYM), pectenotoxin-2 (PTX2) purchased from National Research Council Canada) were prepared as a quality control (QC) sample, as 
well as a blank (water injection) that were analyzed periodically throughout the random sequence of samples.

LC-TOF/MS analysis: An Agilent 1290 Infinity II LC system coupled to an Agilent 6540 UHD Accurate-Mass QTOF hybrid mass spectrometer (Agilent Technologies, Waldbronn, Germany) equipped with a dual electrospray ionization (ESI) source for simultaneous spraying of a mass reference solution to calibrate detected $\mathrm{m} / \mathrm{z}$ ratios continuously was used. The samples were, thus, monitored in high resolution mode. The Agilent Mass Hunter Workstation software (version B.07) was used to process the raw MS data, including extraction of molecular features (MFs), generation of molecular formulas, library searching and database searching. Without additional preparation, aliquots $(5 \mu \mathrm{L})$ of each sample from the supernatant of $H$. ostrearia cultures were separated on a Kinetex $1.7 \mu \mathrm{m} \mathrm{C18} 100 \AA$ (Phenomenex) column $(150 \times 2.1 \mathrm{~mm})$ maintained at $40^{\circ} \mathrm{C}$, with a gradient mobile phase $(0.5$ $\mathrm{mL} \min ^{-1}$ ) comprising $0.1 \%$ aqueous acetic acid (A) and acetonitrile containing $0.1 \%$ acetic acid (B). The gradient was as follows: $5 \% \mathrm{~B}$ from 0 to $2.4 \mathrm{~min}$, rising to $25 \% \mathrm{~B}$ from 2.4 to $4.5 \mathrm{~min}$, to $30 \% \mathrm{~B}$ from 4.5 to $11 \mathrm{~min}$, and to $100 \% \mathrm{~B}$ from 11 to $14 \mathrm{~min}$, maintained until $16.5 \mathrm{~min}$, subsequently decreasing to $5 \% \mathrm{~B}$ until $20 \mathrm{~min}$ and maintained at $5 \% \mathrm{~B}$ until $25 \mathrm{~min}$. This HPLC system was connected to the ultra-high definition quadrupole time-of-flight mass spectrometer Model 6540 Agilent equipped with electrospray Jet Stream Technology, operating in positive or negative ion mode, using the following operation parameters: The capillary voltage, fragmentor voltage and skimmer were set at 3,900, 150 and $60 \mathrm{~V}$, respectively. The sheath gas was at $350{ }^{\circ} \mathrm{C}\left(12 \mathrm{~mL} \mathrm{~min}^{-1}\right)$, the drying gas at $175{ }^{\circ} \mathrm{C}(5 \mathrm{~mL}$ $\min ^{-1}$ ) and the nebulizer at 43 psi. Nitrogen was used as the collision gas. Mass spectra were acquired in full scan analysis over an $\mathrm{m} / \mathrm{z}$ range of 50-1,700 using the extended dynamic range and storage in centroid mode. Our instrument gave a resolution of 15,000 FWHM (Full Width at Half Maximum) at m/z 118.0862 and 30,000 FWHM at m/z 922.0098. To ensure the 
desired mass resolution, continuous internal calibration (Tuning Mix) was performed during analyses by using the signals at m/z 121.0509 (protonated purine) and m/z 922.0098 [protonated hexakis $(1 \mathrm{H}, 1 \mathrm{H}, 3 \mathrm{H}$-tetrafluoropropoxy) phosphazine (HP-921)] in the positive ion mode, while in the negative ion mode ions with $\mathrm{m} / \mathrm{z} 119.0362$ (proton abstracted purine) and m/z 1033.9881 (trifluoroacetic acid adduct of HP-921) were used. For all samples analyzed, three replicates of each analytical sample were injected in the same batch and the order of sample injection was randomized to avoid sample bias. Besides, methanol injections were included every five samples as a blank run to avoid carry-over effects.

Data processing and statistical analysis: all the metabolic profiles are publicly available on the online infrastructure Ifremer Sextant (catalogue of referential data from marine environments; DOI: http://dx.doi.org/10.12770/046e1e6a-864e-48a6-944b-d8613d67de0f).

In this study, several pre-processing steps (feature finding, alignment, filtration and normalization) were used to reduce the large number of data to an operational size and to obtain an adequate set of compounds before applying multivariate analysis. To process all the data obtained by QTOF-MS in full scan MS mode, potential molecular features (MFs) were first extracted from the raw data files using the appropriate algorithm included in the software. The Molecular Feature Extraction (MFE) algorithm was optimized to improve the data extraction of metabolite information with the following parameters: (i) the peak filters were set to centroid height and the minimum threshold absolute abundance of ions was set at 300 counts for negative and positive ionization modes with all charge states allowed for the chromatograms obtained. These cut-off values were established taking into account the low intracellular medium chromatographic background noise samples; (ii) the isotopic distribution to consider MFs valid was defined by two or more ions (with a peak spacing tolerance of $0.002 \mathrm{~m} / \mathrm{z}$, plus $5.0 \mathrm{ppm}$ in mass accuracy); ion and adduct formation in the positive $(+\mathrm{H}$, $+\mathrm{Na})$ and negative ionization $(-\mathrm{H},-2 \mathrm{H}$, ) modes, as well as neutral loss by dehydration, were 
included to identify features corresponding to the same potential metabolite; thus, ions with identical elution profiles and related $\mathrm{m} / \mathrm{z}$ values (representing different adducts or isotopes of the same compound) were extracted as entities characterized by their retention time (RT), intensity in the apex of the chromatographic peaks and accurate mass. In this way, raw data files were created in compound exchange format files (cef files) for each sample and exported into the Mass Profiler Professional software package (MPP version 13.1.1, Agilent Technologies, Santa Clara, CA, USA) for further processing. The parameters of Mass Profiler Professional were set as follows: Created an experiment type: Combined (Identified + Unidentified); Organism: None; Workflow type: Data Import Wizard; Minimum absolute abundance: 500 counts; Compound alignment: RT window $=0.5 \%+0.5 \mathrm{~min}$, Mass window $=15.00 \mathrm{ppm}+2.0 \mathrm{mDa}$; Baseline Option: None.

Identification of the most relevant entities was supported by MS information and searches in the METLIN database (http://metlin.scripps.edu) and the Dictionary of Marine Natural Products (DMNP) library [33,34].

\subsubsection{Identification of bacterial isolates}

Bacterial isolates B5, B10 and B22 were isolated on Marine Agar medium (Difco ${ }^{\mathrm{TM}}$ Marine Broth 2216 supplemented with agar 15 g. $\mathrm{L}^{-1}$ ). The $16 \mathrm{~S}$ rDNA genes of these isolates were amplified, purified and sequenced by Eurofins (Eurofins Medigenomix GmbH). The 1400-bp sequences were submitted to the National Center for Biotechnology Information (NCBI) data bank and compared using BLASTN. 


\subsubsection{Statistical analysis}

Growth curves were established for each triplicate of control (H. ostrearia monoculture) and bacteria-H. ostrearia co-cultures. The data obtained were used in MATLAB R2016b software for fitting to the Gompertz model (Eq. 1), used as a good model to describe growth kinetic data [35].

$$
f(x)=\alpha \exp \left(-\exp \left(\frac{\mu_{\max } \exp (1)}{\alpha}(\lambda-t)+1\right)\right)
$$

Then, in the Gompertz model, $\mathrm{f}(\mathrm{x})$ is expressed in $\ln \left(\right.$ cell $\left.\mathrm{mL}^{-1}\right)$ and $\mathrm{t}$ correspond to time (in days) to obtain maximal concentration in culture. The three fitted parameters, maximum specific growth rate $\left(\mu_{\max }\right.$ in day $\left.{ }^{-1}\right)$, maximum cell concentration $\left(\alpha\right.$ in $\ln$ cell $\left.\mathrm{mL}^{-1}\right)$, and lag time ( $\lambda$ in day) were estimated for each growth curve. Data were expressed as mean of triplicate $(n=3) \pm 95 \%$ confidence interval. Kruskal-Wallis one-way analysis of variance on ranks was carried out for $\mu_{\max }, \alpha$ and $\lambda$. Differences were considered significant at $p<0.05$. To isolate the group or groups that differed from the others, a multiple comparison procedure was used vs. control (i.e., monoculture) with Dunn's method. Sigmastat software (Systat Software, Inc.) was used for all these statistical analyses.

In a second phase, Agglomerative Hierarchical Clustering (AHC) using XLSTAT software (Addinsoft, Inc.) was carried out with mean parameters to detect the cultures that had similar growth kinetic patterns. 


\section{Results and discussion}

\subsection{Isolation of bacteria from Haslea ostrearia cultures}

Bacterial isolates (a total of 28) were chosen for the co-culture tests with $H$. ostrearia based on visual differences: color and appearance of the colonies grown on Petri dishes, and state of the bacteria at the time of their isolation from the algal cultures, i.e., free cells vs. cells associated with $H$. ostrearia in a biofilm form (Table 1). Bacteria were isolated from $H$. ostrearia isolates sampled from three localities out of the 4 (2 from La Tremblade, 21 from Bouin and 5 from Isle de Ré). No cultivable isolate was obtained from La Barre-de-Monts. About half the isolates were recovered from $H$. ostrearia biofilms and the remaining half were from the water column. The differences in bacterial morphotypes from one locality to another were most probably due to the differences in the structure of the bacterial community, as shown in a previous study [28]. Azospirillum brasilense, a plant growth-promoting rhizobacteria (PGPR), known for its ability to stimulate the growth of terrestrial plants and microalgae [36], was included in the set of bacteria to be tested in co-culture with $H$. ostrearia as a potential positive control.

3.2. Bacterial isolates co-cultivated with $H$. ostrearia of La Barre-de-Monts

\subsubsection{Growth performances}

Experiments were performed in plate wells whose advantages have already been reviewed by Bramucci et al.[37]. This non-invasive method, based on chlorophyll fluorescence for measuring algal growth of multiple parallel cultures, has already been used by Le Chevanton et al. [7] and Zecher et al. [38] for the co-culture of the bacterium Rheinheimera sp. strain Tn16 with Thalassiosira pseudonana or Phaeodactylum tricornutum. 
Each bacterial isolate (out of the 28 isolated from the $H$. ostrearia isolates) and $A$. brasilense was co-cultivated with $H$. ostrearia from La Barre-de-Monts (Ho-BM) (Table 1). 
Table 1. Bacteria isolated from H. ostrearia clones: i) geographical origin of the microalga; ii) bacterial state when collected (biofilm vs. water column); iii) H. ostrearia isolates with which bacteria were co-cultivated (Ho-BM: La Barre-de-Monts; Ho-R: Isle de Ré).

\begin{tabular}{|c|c|c|c|c|c|c|c|}
\hline $\begin{array}{l}\text { Id }^{\circ} \text { bacterial } \\
\text { strain }\end{array}$ & $\begin{array}{l}\text { Geographical } \\
\text { origin of } \\
\text { H. ostrearia }\end{array}$ & $\begin{array}{l}\text { Free cells } \\
\text { /biofilms }\end{array}$ & $\begin{array}{l}\text { H. ostrearia } \\
\text { isolates tested } \\
\text { in co-culture }\end{array}$ & $\begin{array}{l}\text { Id }^{\circ} \text { bacterial } \\
\text { strain }\end{array}$ & $\begin{array}{l}\text { Geographical } \\
\text { origin of } \\
\text { H. ostrearia }\end{array}$ & $\begin{array}{l}\text { Free cells } \\
\text { /biofilms }\end{array}$ & $\begin{array}{l}\text { H. ostrearia } \\
\text { isolates tested } \\
\text { in co-culture }\end{array}$ \\
\hline B1 & $\begin{array}{l}\text { Ho La } \\
\text { Tremblade }\end{array}$ & Free cells & Ho-BM & B21 & Ho Bouin & Biofilms & Ho-BM \\
\hline B2 & $\begin{array}{l}\text { Ho La } \\
\text { Tremblade }\end{array}$ & Free cells & Но-BM & B22 & Ho Bouin & Biofilms & Но-BM \\
\hline B5 & Ho Bouin & Biofilms & Ho-BM/Ho-R & B23 & Ho Bouin & Biofilms & Ho-BM \\
\hline B6 & Ho Bouin & Biofilms & Ho-BM & B24 & Ho Bouin & Biofilms & Ho-BM \\
\hline B7 & Ho Bouin & Biofilms & Ho-BM & B25 & Ho Bouin & Biofilms & Ho-BM \\
\hline B9 & Ho Isle de Ré & Biofilms & Ho-BM & B26 & Ho Bouin & Biofilms & Ho-BM/Ho-R \\
\hline B10 & Ho Isle de Ré & Biofilms & Ho-BM/Ho-R & B27 & Ho Bouin & Biofilms & Ho-BM \\
\hline B11 & Ho Isle de Ré & Biofilms & Ho-BM & B29 & Ho Bouin & Free cells & Ho-BM \\
\hline
\end{tabular}




\begin{tabular}{llllllll}
\hline B13 & Ho Isle de Ré & Free cells & Ho-BM & B30 & Ho Bouin & Free cells & Ho-BM \\
\hline B14 & Ho Isle de Ré & Free cells & Ho-BM & B31 & Ho Bouin & Free cells & Ho-BM \\
\hline B17 & Ho Bouin & Free cells & Ho-BM & B33 & Ho Bouin & Free cells & Ho-BM \\
\hline B18 & Ho Bouin & Free cells & Ho-BM & $\mathbf{B 3 4}$ & Ho Bouin & Free cells & Ho-BM \\
\hline B19 & Ho Bouin & Free cells & Ho-BM & $\mathbf{B 3 5}$ & Ho Bouin & Free cells & Ho-BM \\
\hline B20 & Ho Bouin & Free cells & Ho-BM & $\mathbf{B 3 6}$ & Ho Bouin & Free cells & Ho-BM/Ho-R \\
\hline
\end{tabular}


Three typical growth features were observed with the different co-cultures, as shown with the example of the bacterial isolates B5, B10 and B25 (Fig. 1a): i) higher $\lambda$, lower $\mu_{\max }$ and lower $\alpha$ than the control for B25. In this case, these bacteria clearly had a negative effect on the microalgal growth; ii) lower $\lambda$, higher $\mu_{\max }$ and higher $\alpha$ than the control for B10; and iii) higher $\lambda$, higher $\mu_{\max }$ and higher $\alpha$ than the control for B5. A competition for nutrients between bacteria and microalgae most probably established to the benefit of bacteria as shown by Qu et al. [40]. In their study, growth of $C$. vulgaris was promoted at low concentrations of bacteria, whereas opposite trend was observed for treatments with high bacteria density.

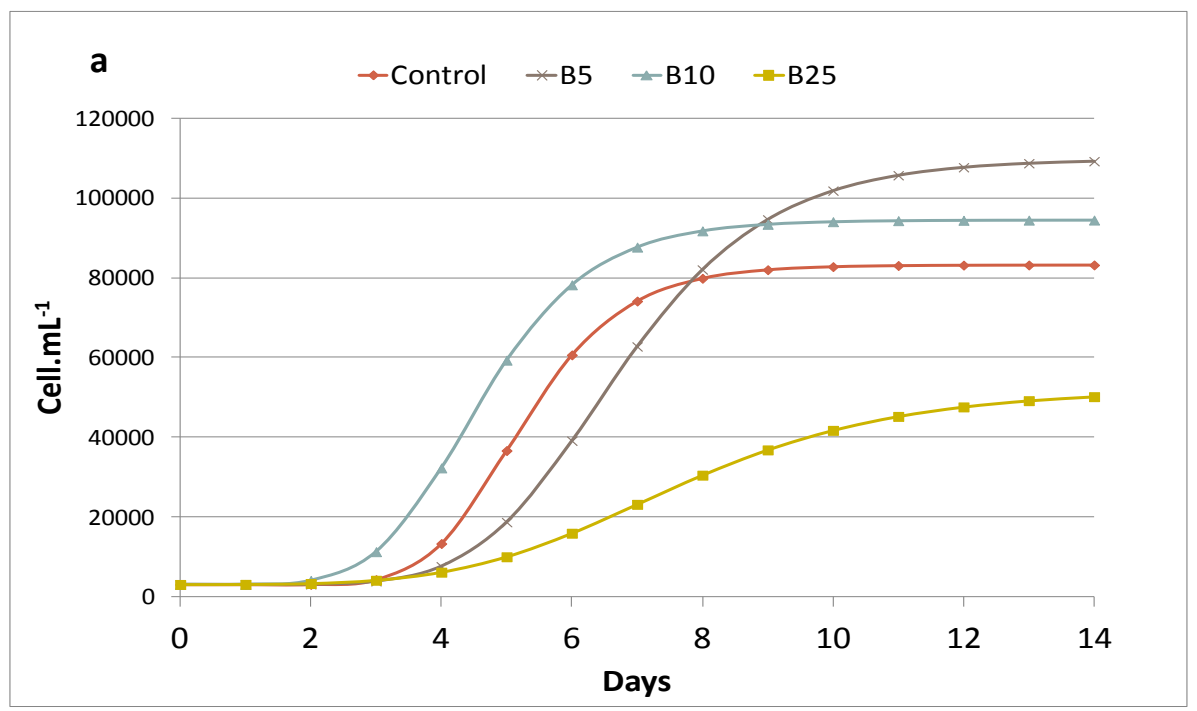



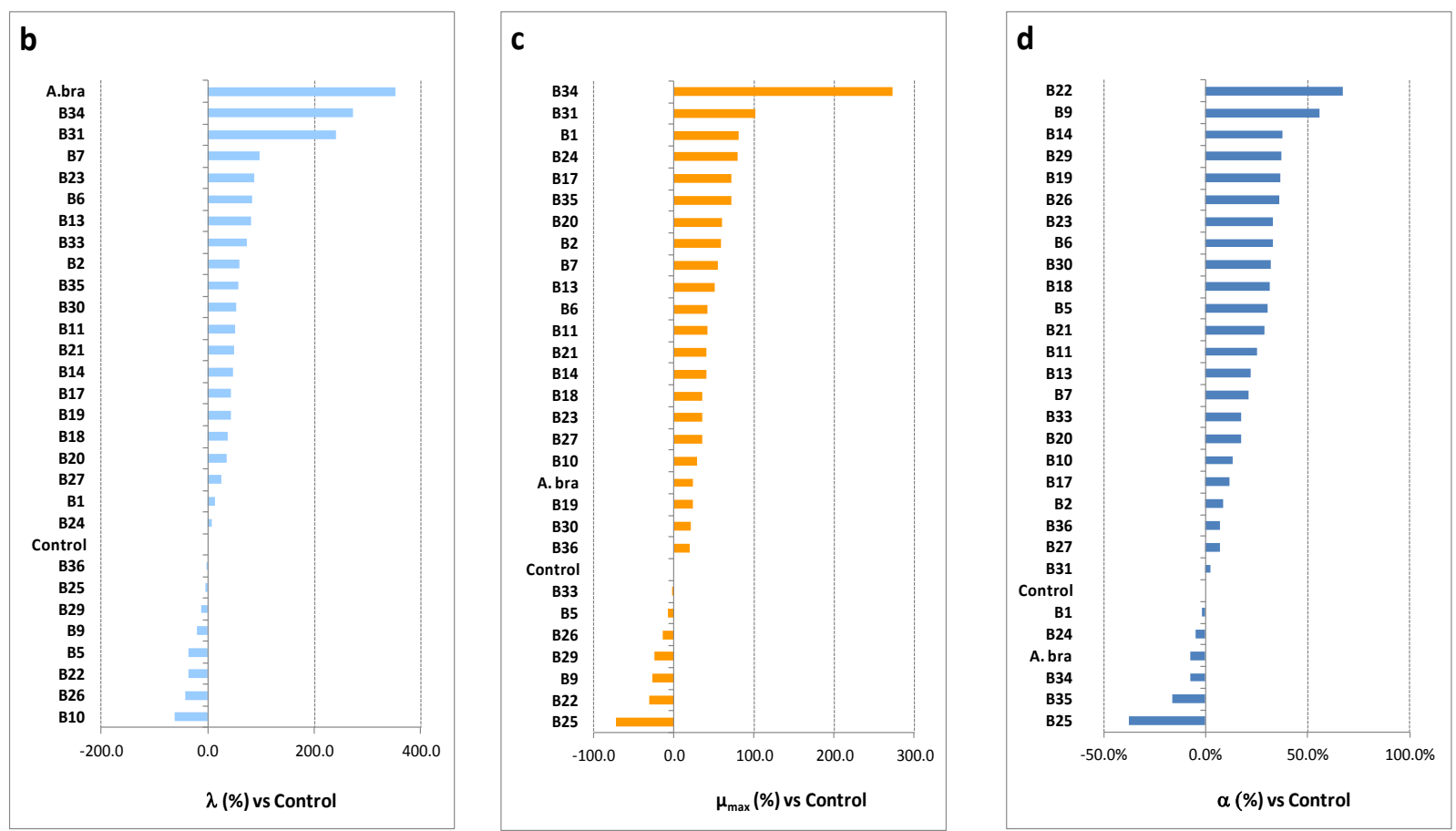

Fig. 1. (a) Typical growth kinetics model of H. ostrearia from La Barre-de-Monts cocultivated with bacteria isolates B5, B10 or B25 and compared to the control (algal monoculture), (b) relative lag time $(\lambda)$, (c) relative maximum specific growth rate $\left(\mu_{\max }\right)$, and (d) relative maximal biomass at the stationary growth stage $(\alpha)$ of $H$. ostrearia (La Barre-deMonts) co-cultivated with each bacterial isolate or A. brasilense (A.bra). Values are expressed as mean of triplicate $(n=3) \pm 95 \%$ confidence interval and are given as a percentage of the control (H. ostrearia monoculture).

Fig. $1 b-d$ focuses on the growth parameters $\left(\lambda, \mu_{\max }, \alpha\right)$ for all bacterial isolates. Compared to the control, the relative lag time $(\lambda)$ decreased up to a maximum of $63 \%$ (Fig. 1b) for the isolates B36, B25, B29, B9, B5, B22, B26 and B10, while it increased for all the others (up to $353 \%$ for $A$. brasilense). When $\lambda$ was higher, it could be hypothesized that the bacteria outcompeted the microalgae (e.g., for nutrients) in the early stage of the culture, as shown by Murphy et al. [39] and Windler et al. [40]. In our study, the higher $\lambda$ values for most algae- 
bacteria associations could also be explained by the simultaneous introduction of bacterial isolates and Ho-BM in the plate wells. To allow the balanced growth of both bacteria and microalgae, bacteria should be added when enough microalgal exudates have been produced to support the bacterial growth itself and also to avoid any bacterial stress towards $H$. ostrearia. In previous studies on the positive effect of bacteria on microalgal growth, no standard condition for the co-cultures was reported. In the study of Suminto and Hirayama [19], the microalgae and the bacteria were inoculated at the same time as in our study. Bi et al. [41] showed that a certain cell density of the bacteria Sphingomonas paucimobilis should be reached to promote the growth of Chlorella vulgaris. On the contrary, Qu et al. [42] showed that the growth of $C$. vulgaris was promoted at low concentrations of bacteria $\left(5 \times 10^{6}\right.$ cells $\mathrm{mL}^{-1}$ ) while an opposite trend was observed for treatments with higher bacterial density $\left(10 \times 10^{6}\right.$ cells $\mathrm{mL}^{-1}$ and $20 \times 10^{6}$ cells $\left.\mathrm{mL}^{-1}\right)$. Wang et al. [20] calculated an optimal bacteria to microalgae ratio for optimal algal growth.

For all bacteria, except B33, B5, B26, B29, B9, B22, and B25, $\mu_{\max }$ was on average $58 \%$ higher and up to a maximum of $272.9 \%$ for B34 (Fig. 1c).

The maximal biomass ( $\alpha$; expressed in $\ln ($ cell concentration)) enables the maximal cell concentration in the stationary growth phase to be estimated. For each co-culture, an increase in $\alpha$ (versus the control) of $27 \%$ on average was observed for 23 out of the 29 bacteria) (Fig. 1d). Although this increase did not exceed $70 \%$ (with B22), it is economically far from negligible. Most studies on co-cultures of bacteria-diatoms showed a positive effect of bacteria on microalgal growth with an increase in the microalgal biomass in the range of what was obtained with $H$. ostrearia $[6,7,19,43]$. It is worth noting that $A$. brasilense did not enhance the microalgal growth, contrary to what was reported by Gonzalez and Bashan [30] when this bacterium was co-cultivated with Chlorella vulgaris. Compared to the algal monoculture, the stationary growth phase $(\alpha)$ of the co-cultures lasted longer for the bacterial 
isolates B1, B5, B7, B9, B22, B24, B25, B31, B33 and B34 (data not shown), as already observed by Suminto and Hirayama [19] for Chaetoceos gracilis and two phytoflagellates (Isochrysis galbana and Pavlova lutheri) co-cultivated with Flavobacterium sp. In contrast, Grossart et al. [44] showed a rapid decline with Thalassiosira rotula associated with a bacterial isolate from the Roseobacter group.

Based on $H$. ostrearia growth criteria $\left(\lambda, \mu_{\max }\right.$ and $\left.\alpha\right)$, with a greater weight being given to $\alpha$ (maximal biomass) as the major parameter for algal producers in aquaculture, the best bacteria were B5, B10 and B22. Compared to $H$. ostrearia monoculture, $\lambda, \mu_{\max }$ and $\alpha$ were $36 \%,-8 \%,+30.6 \%$ for $\mathrm{B} 5,-62 \%,+28 \%,+13.4 \%$ for $\mathrm{B} 10$ and $-37 \%,-31 \%,+67.1 \%$ for $\mathrm{B} 22$, respectively. B5 and B10 were identified as Saccharospirillum sp. and B22 as Rhodobacter sp. The Saccharospirillum genus belongs to the order Oceanospirillum $[45,46]$. Currently, this genus includes three species: S. impatientis [45] and S. salsuginis [47] were isolated from hypersaline environments, and $S$. aesturii was isolated from a tidal flat sediment [48]. Rhodobacter is a purple non-sulfur bacterium (PNSB). PNSB are known to produce plant growth-promoting substances (PGPSs) [49].

Growth performances of Ho-BM in co-culture with the different bacterial isolates were not correlated to the geographical origin of H. ostrearia from which bacteria were isolated nor to the bacterial state (free cells vs. biofilm) at the time of their isolation (see Table 1, Fig. $1 \& 2$ ). We can assume that the isolated bacteria were not specific to the geographical origin of $H$. ostrearia or to the bacterial state. Although the structures of the bacterial communities between the different $H$. ostrearia isolates studied were different [28], all bacteria were considered in that case, while only cultivable bacteria were used here for the selection of the bacterial isolates to be co-cultivated with $H$. ostrearia.

Taking into consideration the three above-mentioned criteria together, i.e., $\lambda, \mu_{\max }$ and $\alpha$ (means of triplicate), homogenous groups were distinguished from the 29 bacteria by 
applying an Ascending Hierarchical Classification (AHC) (Fig. 2). This clearly distinguished two groups of bacteria with a similarity close to zero. Within each group, the similarity between bacteria was $c a .65 \%$, and some bacteria had a similarity close to $100 \%$. The isolates B5 and B10 were logically in the same group (both Saccharospirillum sp.) with a similarity close to $100 \%$ and B22 was in another group (Rhodobacter sp.).

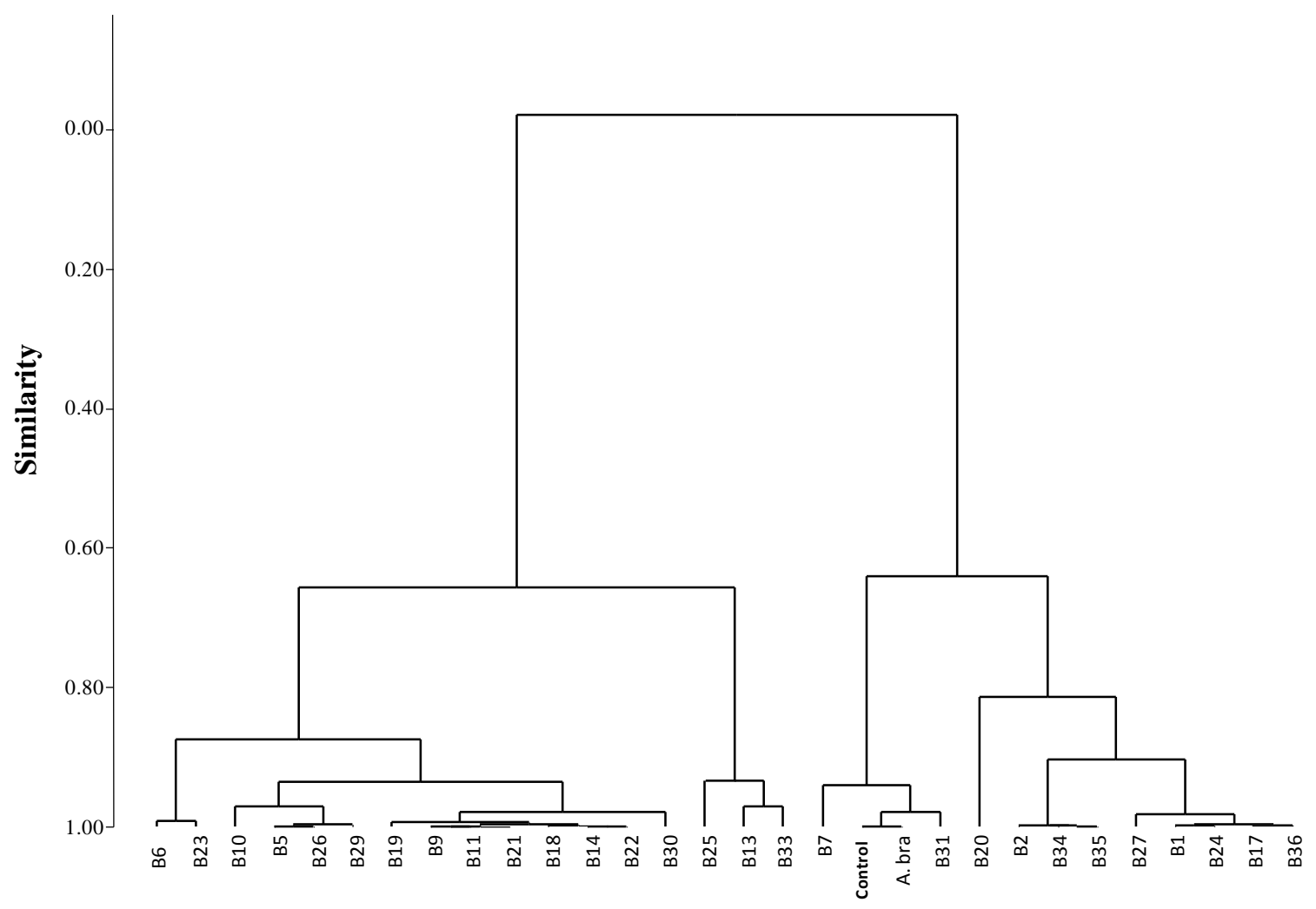

Fig. 2. Ascending Hierarchical Classification (AHC) based on the three parameters of $H$. ostrearia growth (i.e., lag time $(\lambda)$, maximal growth rate $\left(\mu_{\max }\right)$, and maximal algal biomass $(\alpha))$ taken into consideration together. AHC was applied to the 29 bacteria co-cultivated with H. ostrearia from La Barre-de-Monts. Control: Ho-BM monoculture. Experiments were performed in triplicate. 
3.2.2. Effect of the origin of the H. ostrearia isolate (La Barre-de-Monts vs. Isle de Ré) on the microalgal growth in co-culture with bacteria

The effect of the geographical origin of $H$. ostrearia on the algal growth when co-cultivated with a given bacterial isolate was studied. From the different Ho-BM-bacterial associations (Fig. 3), four bacterial isolates with contrasting results on algal growth were co-cultivated with Ho-R (B5, B10, B26 and B36). The two algal isolates were chosen because they harbored the most distinct structure of the bacterial communities [28]. 

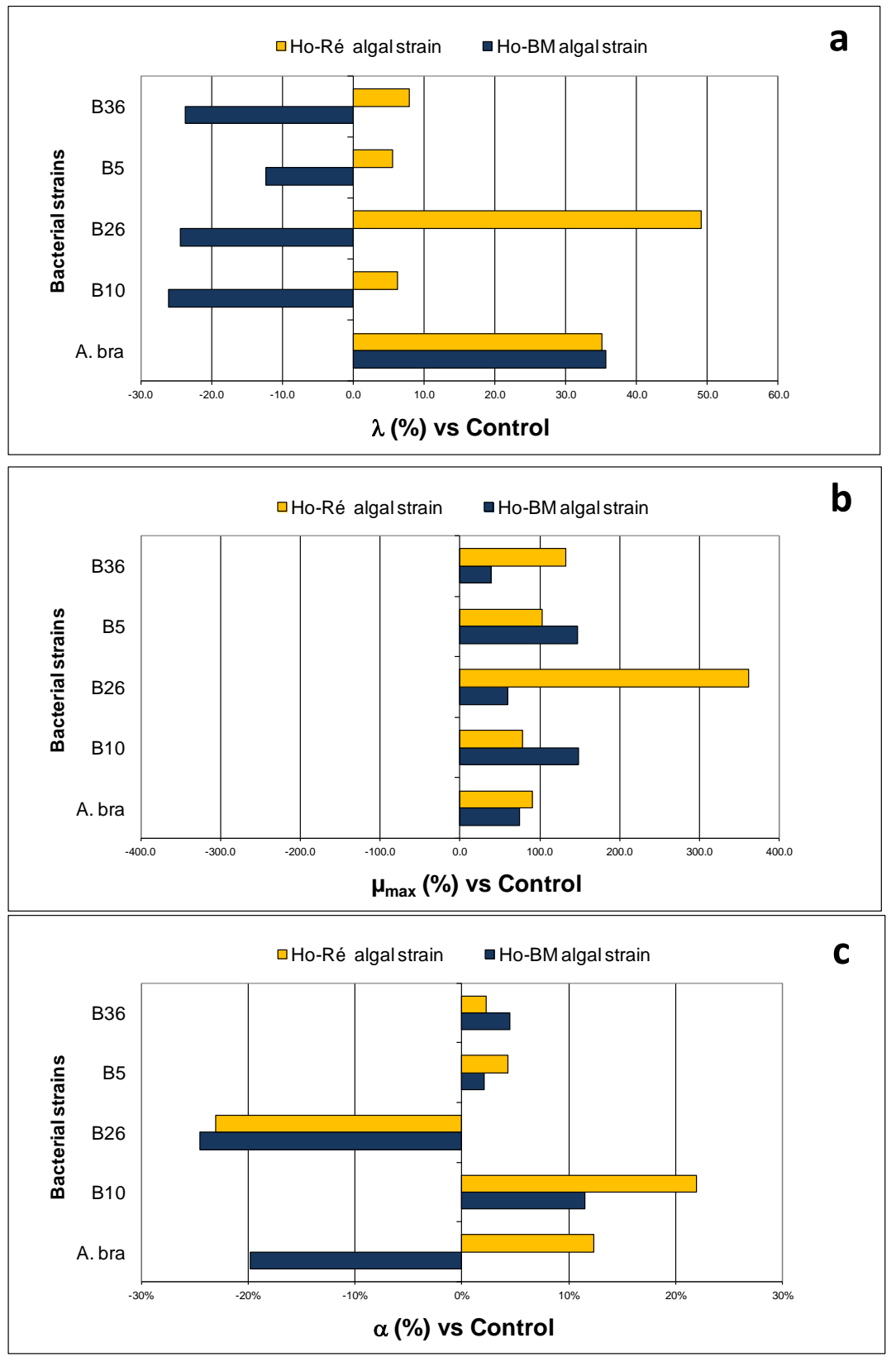

Fig. 3. (a) Lag time $(\lambda)$, (b) maximum specific growth rate $\left(\mu_{\max }\right)$, and (c) maximal biomass at the stationary growth stage $(\alpha)$ of five bacterial strains in co-culture with Ho-BM $(H$. ostrearia La Barre de Monts) and Ho-R (H. ostrearia Isle de Ré). Values are given as a percentage of the control (H. ostrearia monoculture) from average values.

Opposite values of $\lambda$ (Fig. 3a) were obtained (except for A. brasilense) with Ho-BM and Ho$\mathrm{R}$ in co-culture with the bacterial isolates (lower and higher than the control, respectively). 
The higher $\lambda$ with Ho-R could be the result of a competition for nutrients between the bacteria and the microalgae while the lower $\lambda$ with Ho-BM could show a stimulating effect of bacteria. In contrast, the $\mu_{\max }$ (Fig. 3b) of $H$. ostrearia in co-culture with bacteria was higher than the control irrespective of both the geographical origin of H. ostrearia (Ho-BM vs. HoR) and the bacterial isolate. The conclusion was similar for $\alpha$ (Fig. 3c) except with $A$. brasilense (lower than the control for Ho-BM and higher for Ho-R). Overall, it can be concluded from these results that different bacteria first isolated from $H$. ostrearia culture and co-cultivated with different clones of $H$. ostrearia will lead to a relatively similar algal growth. This is not surprising since we showed in a previous study [28] that the structure of the bacterial community in the phycosphere of $H$. ostrearia had $90 \%$ similarity irrespective of the locality where microalgae were recovered, most probably demonstrating the close composition of the microalgal exudates. This finding is obviously an important outcome of this work for aquaculturists. It should be noted that among the 4 bacterial isolates, only B26 shows variable results when Fig. 1 and Fig. 3 were compared. We have no explanation except that the two experiments were not performed at the same time. As compared with most microalgae, H. ostrearia is very sensitive to very small changes in the culture conditions. The composition of the culture medium (seawater used as a base for the culture medium) might have been slightly different. Yet, co-cultures with Ho-Ré and Ho-BM algal strains can be reasonably compared as they were performed at the same time and under the same conditions. Although the bacterial isolates (except $A$. brasilense) acted in the same manner on the growth of Ho-BM and Ho-R (regarding $\mu_{\max }$ and $\alpha$ ), this effect was somewhat modulated, depending on the bacterial isolate. These differences were most probably the result of: i) the difference in size between the two isolates (75.2 $\mu \mathrm{m}$ for Ho-BM; $109.3 \mu \mathrm{m}$ for Ho-R) with a probable repercussion on microalgal physiology; ii) the effect of epiphytic bacteria closely associated with the microalgal cells whose community structure was specific to the microalgal isolate 
[28]. In fact, non-axenic cultures of $H$. ostrearia were deliberately used to simulate culture conditions in aquaculture. Then, the supply of the same bacterial inoculum (called bioaugmentation) to Ho-BM and Ho-R had the most significant impact on algal growth but the epiphytic bacteria, whose community structure was quite different, most probably modulated the effect on algal growth.

3.3. Metabolic fingerprinting differentiation of Haslea ostrearia in combination with bacterial isolates

Metabolomic profiling methods have recently been shown to be a powerful technology for depicting the intrinsic similarities and differences of biological samples by exhaustive profiling and comparison of metabolites in an organism [50,51]. Bacterial isolates B10 and B26 co-cultivated with Ho-R were chosen for their positive $v s$. negative effect, respectively, on the growth of H. ostrearia in the conditions of this study. For the co-culture with Ho-BM, B10 was chosen again for its positive effect and B26 was replaced by $A$. brasilense for its more negative effect on Ho-BM growth. To study the specific relationship between bacteria used in co-culture with $H$. ostrearia isolates in more depth, two $H$. ostrearia controls were used, i.e., axenic and non-axenic cultures.

Considering the complexity of the data generated by the "H. ostrearia" matrix, the same molecular feature extraction (MFE) algorithm method was used to extract the molecular features (MFs) of all samples [52]. Using this chromatographic deconvolution, 4639 peaks were extracted for all samples including co-eluting compounds. The number of these MFs was influenced by the intensity threshold used during the process (300 counts in this study). A preliminary evaluation of data was developed with the four different sample conditions (axenic $v s$. non axenic $H$. ostrearia cultures, positive $v s$. negative effect of bacteria on 
microalgal growth) to check the quality of the samples, to find tendencies of grouping without any a priori hypothesis, and to study the impact of the two considered factors: positive or negative effect of bacteria on $H$. ostrearia growth. Based on mass accuracy and retention time, 2188 compounds out of the 4639 were obtained after applying a filter (frequency analysis) and constituted the compounds (entities) always present (100\%) in at least one condition. These molecular features were subjected to unsupervised analysis approaches, and a Principal Component Analysis (PCA) was first applied as an exploratory analytical method (Fig. 4). This is performed via the transformation of measured variables into uncorrelated principal components, each one being a linear combination of the original variables [53].

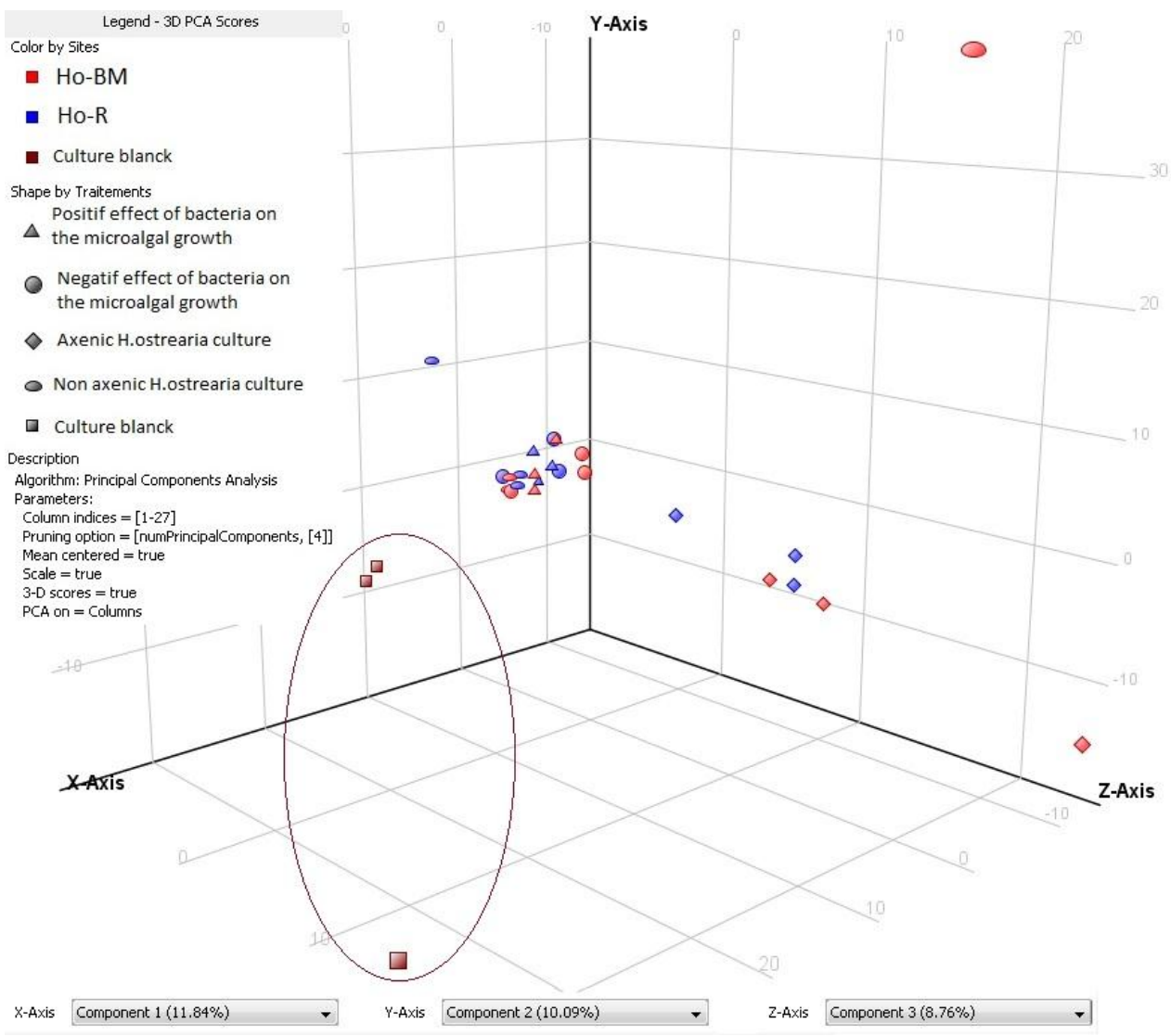

Fig. 4. 3-D principal component analysis (PCA) score plot based on samples $(n=3$ per modality) from Isle de Ré (Ho-R) and La Barre-de-Monts (Ho-BM) cultures associated or not 
with bacteria showing positive (B10) or negative (B26 for Ho-R and A. brasilense for HoBM) effects on algal growth and compared to axenic and non-axenic algal cultures.

The three PCA plotted on the X-, Y-, and Z-axis accounted for only $30.69 \%$ of the total variability in the data set. All the blanks (i.e., culture medium without microalgae or bacteria) and axenic microalgal cultures were clearly separated between themselves and the rest of the samples (i.e., non-axenic algal culture, bacteria-microalgae co-cultures). On the contrary for non-axenic algal culture and bacteria-microalgae co-cultures, PCA analysis was unable to show differences between modalities in which bacteria had a positive effect on $H$. ostrearia growth and those with a negative effect. Moreover PCA did not reveal differences according to the geographical origin of $H$. ostrearia isolates (Ho-R vs. Ho-BM).

To attempt to highlight differences between the different co-culture modalities, only the compounds that were detected in all replicates for each modality were considered and a Venn diagram was produced (Fig. 5). Venn diagrams are visual representations of mathematical sets [54] and were computed with the Mass Profiler Professional software (MPP) solution. These diagrams show both the compounds shared by all the modalities and the compounds specific to each modality. Firstly, 99 compounds were common to all samples, which explains why the PCA was unable to differentiate sample groups. For the Ho-R isolate (Fig. 5a), overall 160 compounds were identified when bacteria isolate B10 with a positive effect on algal growth was used, and 155 compounds for bacteria isolate B26 with a negative effect on algal growth. Once the compounds affiliated to the axenic and non-axenic cultures were removed, i.e., 128 and 165 compounds, respectively, 6 specific compounds remained for the bacteria B10-Ho-R co-culture and 7 for the bacteria B26-Ho-R co-culture with 3 compounds in common. It is noteworthy that 5 compounds were specific to the axenic algal cultures and 8 to the nonaxenic ones. 
The same analysis was performed for Ho-BM (Fig. 5b). The distribution of the compounds between the modalities was similar with, however, 2 more specific metabolites for Ho-BM (16) compared to Ho-R (8) without any repercussion on the number of specific metabolites relative to the co-cultures ( 3 and 4 specific metabolites for positive and negative bacterial effects on H. ostrearia growth).

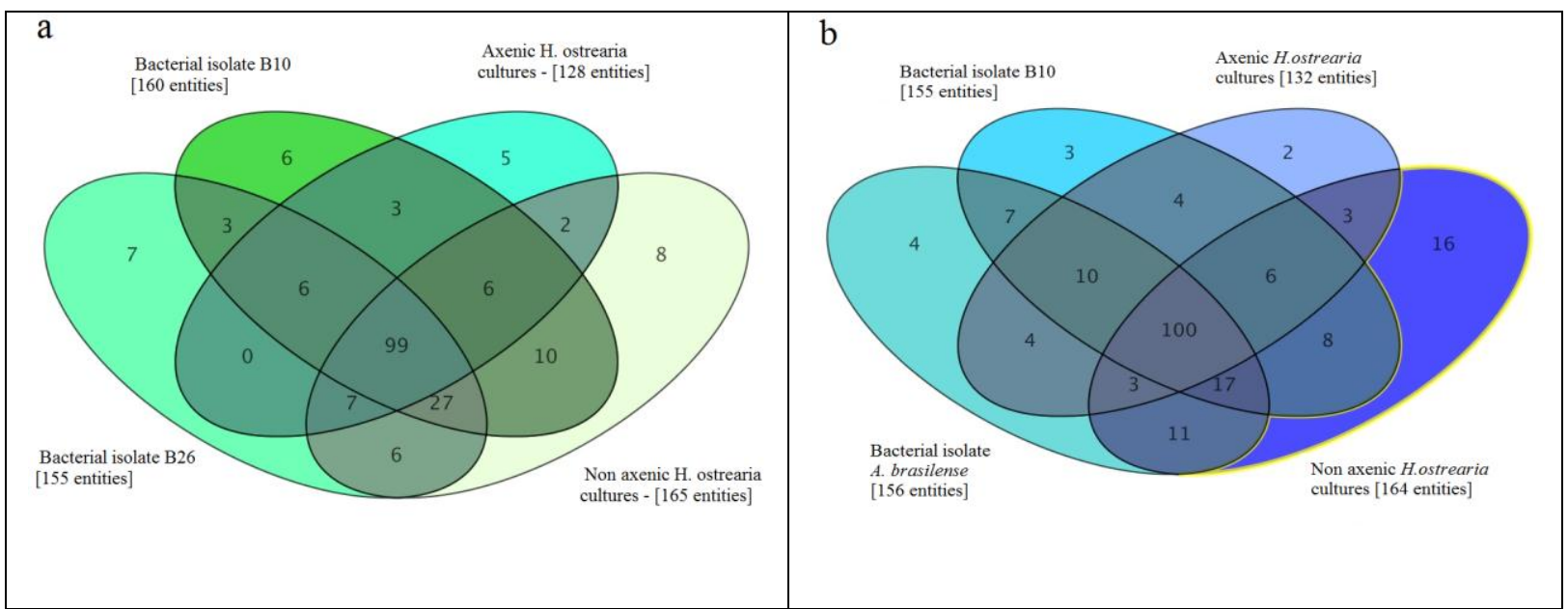

Fig. 5. Venn diagrams showing the common and specific compounds based on the samples (n $=3$ per modality, non-averaged, Filtered by Frequency with cut-off percentage: 100) from: a) Isle de Ré (Ho-R) cultures associated or not with bacteria showing positive (B10) or negative (B26) effects on algal growth and compared to axenic and non-axenic algal cultures; b) La Barre-de-Monts (Ho-BM) cultures associated or not with bacteria showing positive (B10) or negative (A. brasilense) effects on algal growth and compared to axenic and non-axenic algal cultures.

The literature has given evidence of extracellular indole acetic acid (IAA) production in two axenic cultures and recently, the identification of IAA as well as another metabolite, phenylacetic acid (PAA), also known to be an auxin that improves algal growth [55], have been detected by Segev et al. [56] in instrumental conditions sufficiently close to our 
innovative metabolomic approach to allow us a retrospective detection of nitrogen-containing IAA $[\mathrm{M}+\mathrm{H}]$ (Fig. 6). One might have expected IAA production in bacteria-H. ostrearia cocultures more than with axenic microalgae. Yet it was shown that axenic green microalgae (Scenedesmus armatus and Chlorella pyrenoidosa) were able to produce and release IAA to the culture medium [57]. In the case of co-cultures, one can assume that IAA produced by bacteria was immediately metabolized by $H$. ostrearia.
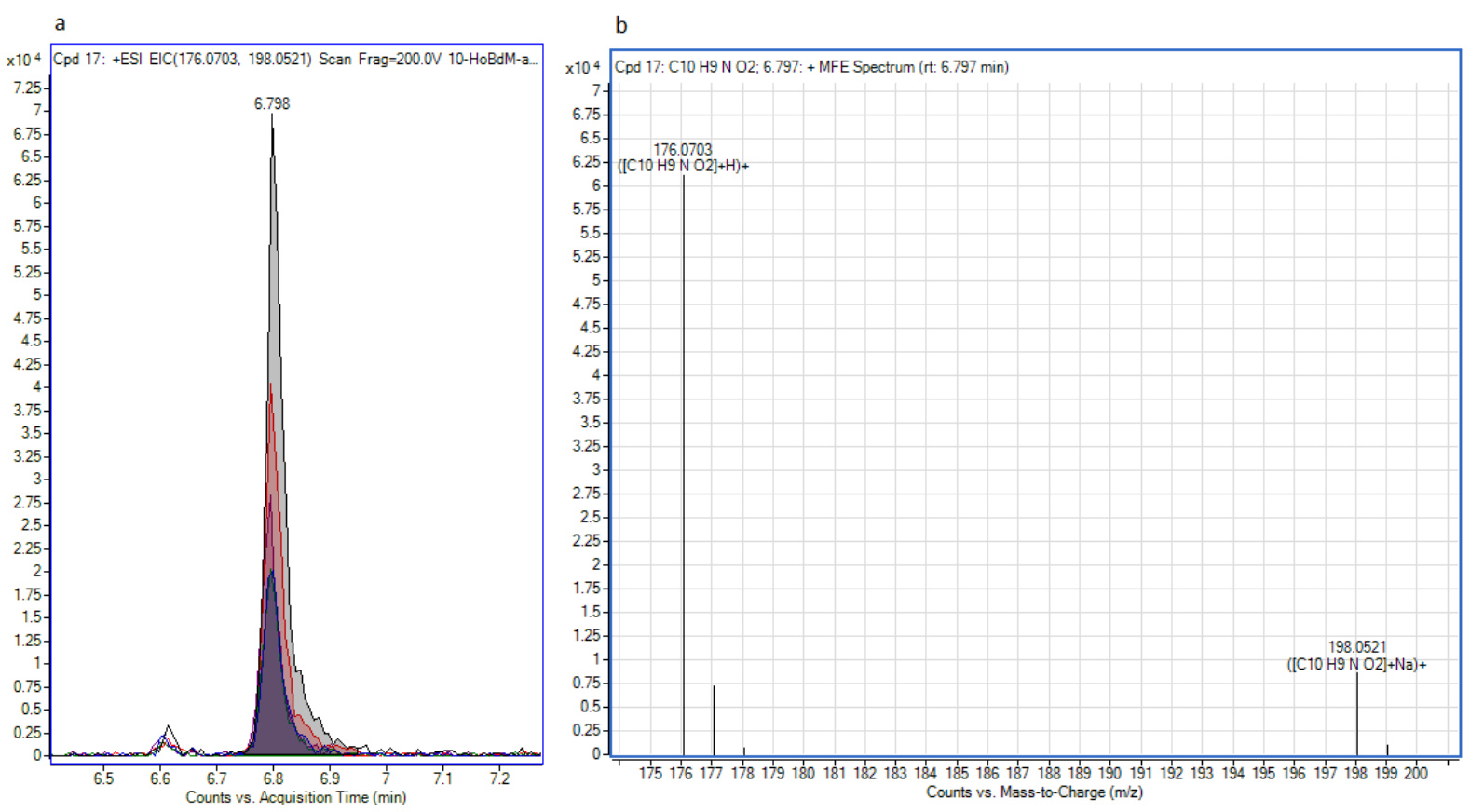

Fig. 6. a) First window is abundances of extracted ion (EIC, $\mathrm{m} / \mathrm{z}$ 176.0706) overlays of an indole acetic acid (IAA) metabolite detected in triplicate in axenic La Barre-de-Monts (HoBM) (grey) and Isle de Ré (Ho-R) (red) cultures; b) spectrum for sample Ho-BM with the IAA monoisotopic mass, its isotopic pattern and its sodium adducts. Data were processed using Agilent Profinder Software (B.08.00).

In addition, IAA is only and strictly found as 1 of the 5 metabolites specific group to the axenic condition of Ho-R (Fig. 5a) while it is part of 1 of 2 metabolites isolated as specific to 
the Ho- BM. As expected in Fig. 5a,b, represented respectively by the compartment with 6 metabolites for Ho-R (Fig. 5a) and the compartment with 3 metabolites for Ho-BM (Fig.5b) the IAA is not retained as a potential candidate to associate with the positive effect of the bacterial presence to improve algal growth. Nevertheless, it is necessary to weight this observation with the fact that, within the various biosynthetic pathways [58] of IAA, this compound is very labile. On the contrary, can be considered very interesting the presence of IAA without a priori signals only in the axenic form of the microalgae, but nevertheless present in the isolates from two different geographical zones (La Barre-de-Mont and Isle de Ré).

Of the 2188 metabolites that make up our dataset, we observed that one hundred compounds defined the different groups and that the number of compounds specific to each group was in the order of about ten units. This is typical for plankton studies, where low abundance signals are encountered in a complex matrix $[59,60]$. Irrespective of the $H$. ostrearia origin, the common compounds solely specific to a bacterial positive effect on $H$. ostrearia growth, i.e., 6 for Ho-R and 3 for Ho-BM (Fig. 7a), were clustered. No common compound were identified in this step. The two compartments (green and blue) were then compared to the compartment (yellow) which represents the 235 compounds detected in the culture medium (Fig. 7b) composed of seawater enriched with mineral salts (see "Material and Methods" section). By subtracting the compounds belonging to the algal growth medium, this operation allowed to conclude that only 3 and 1 compounds were specific Ho-R and Ho-BM respectively. 


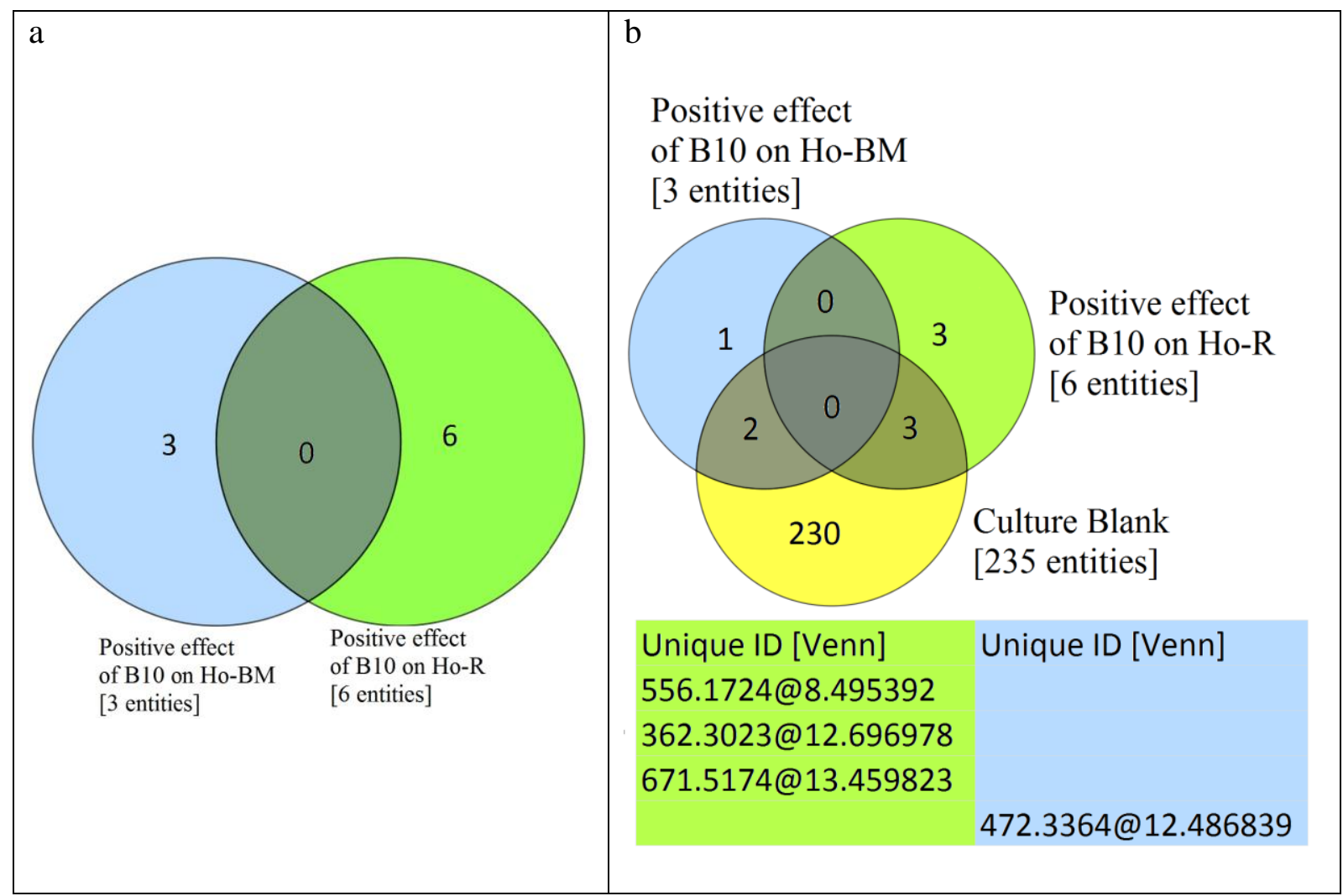

Fig. 7. Venn diagrams showing the compound distribution between La Barre-de-Monts (Ho-

$\mathrm{BM}$ ) and Isle de Ré (Ho-R) isolates in co-culture with the bacteria isolate B10 (positive effect on algal growth): a) comparison of common compounds in growth activation for Ho-BM and Ho-R; b) metabolites specific (mass@ Retention time) to growth activation for Ho-BM and Ho-R after subtracting the compounds specific to the culture medium.

The most specific compounds with a significance threshold of $p$-value $\leq 0.05$ and a fold change $\geq 2.0$ (i.e., 1 compound for Ho-BM and 3 for Ho-R: see Fig. 7b) were tentatively elucidated by METLIN and DMNP databases. The most probable elemental composition was calculated for each metabolite, based on the accurate mass and isotope distribution pattern (Table 3). 
Table 3. Putative elemental composition (METLIN or DMNP database) for 4 compounds involved in the growth activation process.

\begin{tabular}{|c|c|c|c|c|c|c|c|c|c|}
\hline $\begin{array}{l}\text { Compound number } \\
\text { (positive polarity) }\end{array}$ & $\begin{array}{c}\text { Elemental } \\
\text { composition }\end{array}$ & Score & RT & Height & Mass & Ions* & $\begin{array}{c}\text { Mass } \\
(\mathrm{MFG})^{* *}\end{array}$ & $\begin{array}{c}\text { Mass difference } \\
(\mathbf{p p m}) * * *\end{array}$ & Spectrum \\
\hline 1 & $\mathrm{C}_{24} \mathrm{H}_{46} \mathrm{~N}_{3} \mathrm{O}_{6}$ & 89.06 & 12.487 & 22784 & 472.3364 & 3 & 472.3387 & 4.7 & see Suppl. Fig 1 \\
\hline 2 & $\mathrm{C}_{30} \mathrm{H}_{26} \mathrm{~N}_{3} \mathrm{O}_{8}$ & 98.05 & 8.495 & 274698 & 556.1723 & 8 & 556.172 & -0.49 & see Suppl. Fig 2 \\
\hline 3 & $\mathrm{C}_{18} \mathrm{H}_{40} \mathrm{~N}_{3} \mathrm{O}_{4}$ & 98.28 & 12.697 & 43222 & 362.3023 & 5 & 362.3019 & -1.26 & see Suppl. Fig 3 \\
\hline 4 & $\mathrm{C}_{44} \mathrm{H}_{67} \mathrm{~N}_{2} \mathrm{O}_{3}$ & 96.88 & 13.46 & 10100 & 671.5158 & 3 & 671.5152 & -0.41 & see Suppl. Fig 4 \\
\hline
\end{tabular}

* Number of ions identified as belonging to a compound

** Mass of "M" calculated from the proposed formula

*** Difference between the observed mass and the mass of the best generated for the formula 
For metabolomics research, especially when applied to non-sequenced organisms, very many peaks remain unidentified [61]. Complementary MS and NMR methods need to be developed for proper matching metabolite identification. Unsurprisingly, our compounds were identified as unknown; nevertheless the high score (>95) obtained is an encouraging result.

\section{Conclusion}

Irrespective of their state (as suspended cells or in a biofilm form), when recovered from monospecific cultures of $H$. ostrearia, most bacteria isolated co-cultivated with this microalgae increased the microalgal biomass, which may create opportunities for aquaculturists who produce green oysters. Nonetheless, this result should be validated at fullscale. This study also highlighted, from the metabolic profiles of the extracellular compounds synthesized by both $H$. ostrearia and added bacteria, a few not fully identified compounds shown to be synthesized specifically by bacteria that stimulate microalgal growth. These data give new original insights in the understanding of the relationships between bacteria and diatoms, and more especially $H$. ostrearia.

\section{Acknowledgements}

This study was carried out under the COSELMAR project supported by IFREMER and Nantes University and funded by the Regional Council of the Pays de la Loire, France. We would like to thank Dr Yoav Bashan for providing us with the strain of Azospirillum brasilense and the LBPV laboratory (University of Nantes) for permission to use their fluorimeter. 


\section{Author contributions}

The following authors have participated sufficiently in the work described in the manuscript to take public responsibility for appropriate parts of the content. Each author's contributions relating to sections (1), (2) \& (3) are mentioned below:

- Régis BARON: conception and design of the study, revising it critically, final approval of the version

- Hervé CAPIAUX: acquisition of data, drafting the article, final approval of the version

- Quentin GRANDET-MARCHANT; acquisition of data, analysis and interpretation of the data, final approval of the version

- Thierry LEBEAU: conception and design of the study, drafting the article, final approval of the version \& responsible for the integrity of the work as a whole, from inception to finished article (Thierry.lebeau@univ-nantes.fr)

- Alexandra LEPINAY: conception and design of the study, drafting the article, final approval of the version

- Florence MONDEGUER: experimental design study, acquisition of data, drafting the article, final approval of the version

- Vincent TURPIN: conception and design of the study, drafting the article, final approval of the version

\section{Conflict of interest}

The authors declare that there are no conflicts of interest. 


\section{Animal use}

No animal use.

\section{References}

[1] T. Lebeau, J.-M. Robert, Diatom cultivation and biotechnologically relevant products. Part II: Current and putative products, Appl. Microbiol. Biotechnol. 60 (2003) 624-632. doi:10.1007/s00253-002-1177-3.

[2] W. Bell, R. Mitchell, Chemotactic and growth responses of marine bacteria to algal extracellular products, Biol. Bull. 143 (1972) 265-277. doi:10.2307/1540052.

[3] J.N. Rooney-Varga, M.W. Giewat, M.C. Savin, S. Sood, M. LeGresley, J.L. Martin, Links between phytoplankton and bacterial community dynamics in a coastal marine environment, Microb. Ecol. 49 (2005) 163-175. doi:10.1007/s00248-003-1057-0.

[4] F.M.I. Natrah, P. Bossier, P. Sorgeloos, F.M. Yusoff, T. Defoirdt, Significance of microalgalbacterial interactions for aquaculture, Rev. Aquac. 6 (2014) 48-61. doi:10.1111/raq.12024.

[5] S. Smriga, V. Ignacio Fernandez, J. Mitchell, R. Stocker, Chemotaxis toward phytoplankton drives organic matter partitioning among marine bacteria, 2016. doi:10.1073/pnas.1512307113.

[6] R. Ramanan, B.-H. Kim, D.-H. Cho, H.-M. Oh, H.-S. Kim, Algae-bacteria interactions: Evolution, ecology and emerging applications, Biotechnol. Adv. 34 (2016) 14-29. doi:10.1016/j.biotechadv.2015.12.003.

[7] M. Le Chevanton, M. Garnier, G. Bougaran, N. Schreiber, E. Lukomska, J.-B. Bérard, E. Fouilland, O. Bernard, J.-P. Cadoret, Screening and selection of growth-promoting bacteria for Dunaliella cultures, Algal Res. 2 (2013) 212-222. doi:10.1016/j.algal.2013.05.003.

[8] J. Fuentes, I. Garbayo, M. Cuaresma, Z. Montero, M. González-del-Valle, C. Vílchez, Impact of Microalgae-Bacteria Interactions on the Production of Algal Biomass and Associated Compounds, Mar. Drugs. 14 (2016) 100. doi:10.3390/md14050100.

[9] E.F.Y. Hom, P. Aiyar, D. Schaeme, M. Mittag, S. Sasso, A chemical perspective on microalgalmicrobial interactions, Trends Plant Sci. 20 (2015) 689-693. doi:10.1016/j.tplants.2015.09.004.

[10] S.A. Amin, M.S. Parker, E.V. Armbrust, Interactions between Diatoms and Bacteria, Microbiol. Mol. Biol. Rev. 76 (2012) 667-684. doi:10.1128/MMBR.00007-12.

[11] M. Sapp, A.S. Schwaderer, K.H. Wiltshire, H.-G. Hoppe, G. Gerdts, A. Wichels, Species-specific bacterial communities in the phycosphere of microalgae?, Microb. Ecol. 53 (2007) 683-699. doi:10.1007/s00248-006-9162-5.

[12] H. Schäfer, B. Abbas, H. Witte, G. Muyzer, Genetic diversity of 'satellite' bacteria present in cultures of marine diatoms, FEMS Microbiol. Ecol. 42 (2002) 25-35. doi:10.1111/j.15746941.2002.tb00992.x.

[13] M. Guannel, M. Horner-Devine, G. Rocap, Bacterial community composition differs with species and toxigenicity of the diatom Pseudo-nitzschia, Aquat. Microb. Ecol. 64 (2011) 117133. doi:10.3354/ame01513.

[14] D. Schwenk, L. Nohynek, H. Rischer, Algae-bacteria association inferred by 165 rDNA similarity in established microalgae cultures, MicrobiologyOpen. 3 (2014) 356-368. doi:10.1002/mbo3.175. 
[15] S.A. Amin, L.R. Hmelo, H.M. van Tol, B.P. Durham, L.T. Carlson, K.R. Heal, R.L. Morales, C.T. Berthiaume, M.S. Parker, B. Djunaedi, A.E. Ingalls, M.R. Parsek, M.A. Moran, E.V. Armbrust, Interaction and signalling between a cosmopolitan phytoplankton and associated bacteria, Nature. 522 (2015) 98-101. doi:10.1038/nature14488.

[16] C.G. Bruckner, R. Bahulikar, M. Rahalkar, B. Schink, P.G. Kroth, Bacteria Associated with Benthic Diatoms from Lake Constance: Phylogeny and Influences on Diatom Growth and Secretion of Extracellular Polymeric Substances, Appl. Environ. Microbiol. 74 (2008) 77407749. doi:10.1128/AEM.01399-08.

[17] B.-H. Kim, R. Ramanan, D.-H. Cho, H.-M. Oh, H.-S. Kim, Role of Rhizobium, a plant growth promoting bacterium, in enhancing algal biomass through mutualistic interaction, Biomass Bioenergy. 69 (2014) 95-105. doi:10.1016/j.biombioe.2014.07.015.

[18] J. Liu, A.J. Lewitus, P. Brown, S.B. Wilde, Growth-promoting effects of a bacterium on raphidophytes and other phytoplankton, Harmful Algae. 7 (2008) 1-10. doi:10.1016/j.hal.2007.04.009.

[19] Suminto, K. Hirayama, Application of a growth-promoting bacteria for stable mass culture of three marine microalgae, in: A. Hagiwara, T.W. Snell, E. Lubzens, C.S. Tamaru (Eds.), Live Food Aquac., Springer Netherlands, Dordrecht, 1997: pp. 223-230. doi:10.1007/978-94-0172097-7_35.

[20] R. Wang, Y. Tian, S. Xue, D. Zhang, Q. Zhang, X. Wu, D. Kong, W. Cong, Enhanced microalgal biomass and lipid production via co-culture of Scenedesmus obliquus and Candida tropicalis in an autotrophic system: Enhanced microalgal biomass and lipid production, J. Chem. Technol. Biotechnol. 91 (2016) 1387-1396. doi:10.1002/jctb.4735.

[21] R. Wang, S. Xue, D. Zhang, Q. Zhang, S. Wen, D. Kong, C. Yan, W. Cong, Construction and characteristics of artificial consortia of Scenedesmus obliquus -bacteria for S. obliquus growth and lipid production, Algal Res. 12 (2015) 436-445. doi:10.1016/j.algal.2015.10.002.

[22] G. Ranson, L'Absorption de matières organiques dissoutes par la surface expérieure du corps chez les animaux aquatiques., 1927.

[23] J.M. Robert, J. Pages, D. Prat, Applications de la biometrie cytologique a la definition des stades de developpement du Navicula ostrearia Bory: incidences de l'evolution pigmentaire sur le verdissement des claires a huitres, Physiol. Végétale. (1975). http://agris.fao.org/agrissearch/search.do?recordID=US201302763875 (accessed November 9, 2017).

[24] R. Gastineau, N. Davidovich, G. Hansen, J. Rines, A. Wulff, I. Kaczmarska, J. Ehrman, D. Hermann, F. Maumus, Y. Hardivillier, V. Leignel, B. Jacquette, V. Méléder, G. Hallegraeff, M. Yallop, R. Perkins, J.-P. Cadoret, B. Saint-Jean, G. Carrier, J.-L. Mouget, Haslea ostrearia-like Diatoms: Biodiversity out of the Blue, in: Adv. Bot. Res., Elsevier, 2014: pp. 441-465. doi:10.1016/B978-0-12-408062-1.00015-9.

[25] H. Schubert, G. Tremblin, J.-M. Robert, S. Sagert, Y. Rincé, In-vivo fluorescence measurement of photosynthesis of Haslea ostrearia Simonsen in relation to marennine content, Diatom Res. 10 (1995) 341-349. doi:10.1080/0269249X.1995.9705354.

[26] C. Minier, R. Tutundjian, F. Galgani, J.M. Robert, Copper tolerance in Haslea ostrearia assessed by measurements of in vivo esterase activity, Mar. Environ. Res. 46 (1998) 579-582. doi:10.1016/S0141-1136(97)00077-9.

[27] M. Rech, Effets de l'éclairement visible et ultraviolet sur la croissance et la photosynthèse de microalgues: incidences sur l'écophysiologie du phytoplancton des claires ostréicoles, Thèse de doctorat, Université du Maine (Le Mans). UFR de sciences exactes et naturelles, 2004.

[28] A. Lépinay, H. Capiaux, V. Turpin, F. Mondeguer, T. Lebeau, Bacterial community structure of the marine diatom Haslea ostrearia, Algal Res. 16 (2016) 418-426.

doi:10.1016/j.algal.2016.04.011. 
[29] T. Lebeau, G.-A. Junter, T. Jouenne, J.-M. Robert, Marennine production by agar-entrapped Haslea ostrearia Simonsen, Bioresour. Technol. 67 (1999) 13-17. doi:10.1016/S09608524(99)00096-6.

[30] L.E. Gonzalez, Y. Bashan, Increased growth of the microalga Chlorella vulgaris when coimmobilized and cocultured in alginate beads with the Plant-Growth-Promoting Bacterium Azospirillum brasilense, Appl. Environ. Microbiol. 66 (2000) 1527-1531. doi:10.1128/AEM.66.4.1527-1531.2000.

[31] F. Mondeguer, J.-P. Antignac, Y. Guitton, F. Monteau, S. Le Borgne, P. Hess, Nouvelle stratégie de caractérisation non ciblée de type métabolomique au service de l'identification de composés bioactifs accumulés dans les mollusques bivalves, Spectra Anal. (2012) 24-33.

[32] Z. Zendong, M. Sibat, C. Herrenknecht, P. Hess, P. McCarron, Relative molar response of lipophilic marine algal toxins in liquid chromatography/electrospray ionization mass spectrometry, Rapid Commun. Mass Spectrom. 31 (2017) 1453-1461. doi:10.1002/rcm.7918.

[33] J.W. Blunt, B.R. Copp, W.-P. Hu, M.H.G. Munro, P.T. Northcote, M.R. Prinsep, Marine natural products, Nat. Prod. Rep. 25 (2008) 35. doi:10.1039/b701534h.

[34] J.-L. Wolfender, G. Marti, A. Thomas, S. Bertrand, Current approaches and challenges for the metabolite profiling of complex natural extracts, J. Chromatogr. A. 1382 (2015) 136-164. doi:10.1016/j.chroma.2014.10.091.

[35] M.H. Zwietering, I. Jongenburger, F.M. Rombouts, K. van't Riet, Modeling of the Bacterial Growth Curve, Appl. Environ. Microbiol. 56 (1990) 1875-1881.

[36] T.M. Tien, M.H. Gaskins, D.H. Hubbell, Plant Growth Substances Produced by Azospirillum brasilense and their effect on the growth of Pearl Millet ( Pennisetum americanum L.), Appl. Environ. Microbiol. 37 (1979) 1016.

[37] A.R. Bramucci, L. Labeeuw, T.J. Mayers, J.A. Saby, R.J. Case, A small volume bioassay to assess bacterial/phytoplankton co-culture using WATER-Pulse-Amplitude-Modulated (WATER-PAM) fluorometry, J. Vis. Exp. (2015). doi:10.3791/52455.

[38] K. Zecher, N. Jagmann, P. Seemann, B. Philipp, An efficient screening method for the isolation of heterotrophic bacteria influencing growth of diatoms under photoautotrophic conditions, J. Microbiol. Methods. 119 (2015) 154-162. doi:10.1016/j.mimet.2015.10.016.

[39] T. Murphy, D. Lean, C. Nalewajko, Blue-green algae: their excretion of iron-selective chelators enables them to dominate other algae, Science. 192 (1976) 900-902. doi:10.1126/science.818707.

[40] M. Windler, D. Bova, A. Kryvenda, D. Straile, A. Gruber, P.G. Kroth, Influence of bacteria on cell size development and morphology of cultivated diatoms: Bacterial influence on diatom cultures, Phycol. Res. 62 (2014) 269-281. doi:10.1111/pre.12059.

[41] X. Bi, K. Xing, W. Zhou, X. Tang, Detection of Acylated Homoserine Lactone (AHL) in the heterotrophic bacteria Z-TG01 and its ecological action on the algae, $<i>$ Chlorella vulgaris $<i />$, Isr. J. Aquac. - Bamidgeh. 64 (2012) 7.

[42] L. Qu, R. Wang, P. Zhao, R. Chen, W. Zhou, L. Tang, X. Tang, Interaction between Chlorella vulgaris and bacteria: interference and resource competition, Acta Oceanol. Sin. 33 (2014) 135-140. doi:10.1007/s13131-014-0432-7.

[43] H. Wang, R.T. Hill, T. Zheng, X. Hu, B. Wang, Effects of bacterial communities on biofuelproducing microalgae: stimulation, inhibition and harvesting, Crit. Rev. Biotechnol. 36 (2016) 341-352. doi:10.3109/07388551.2014.961402.

[44] H. Grossart, M. Simon, Interactions of planktonic algae and bacteria: effects on algal growth and organic matter dynamics, Aquat. Microb. Ecol. 47 (2007) 163-176. doi:10.3354/ame047163.

[45] M. Labrenz, Saccharospirillum impatiens gen. nov., sp. nov., a novel gamma-Proteobacterium isolated from hypersaline Ekho Lake (East Antarctica), Int. J. Syst. Evol. Microbiol. 53 (2003) 653-660. doi:10.1099/ijs.0.02406-0. 
[46] G.M. Garrity, J.A. Bell, T. Lilburn, Oceanospirillales ord. nov., in: D.J. Brenner, N.R. Krieg, J.T. Staley, G.M. Garrity, D.R. Boone, P. De Vos, M. Goodfellow, F.A. Rainey, K.-H. Schleifer (Eds.), Bergey's Manual ${ }^{\circledR}$ Syst. Bacteriol. Vol. Two Proteobacteria Part B Gammaproteobacteria, Springer US, Boston, MA, 2005: pp. 270-323. doi:10.1007/0-387-28022-7_8.

[47] Y.-G. Chen, X.-L. Cui, Q.-Y. Li, Y.-X. Wang, S.-K. Tang, Z.-X. Liu, M.-L. Wen, Q. Peng, L.-H. Xu, Saccharospirillum salsuginis sp. nov., a gammaproteobacterium from a subterranean brine, Int. J. Syst. Evol. Microbiol. 59 (2009) 1382-1386. doi:10.1099/ijs.0.003616-0.

[48] A. Choi, H.-M. Oh, J.-C. Cho, Saccharospirillum aestuarii sp. nov., isolated from tidal flat sediment, and an emended description of the genus Saccharospirillum, Int. J. Syst. Evol. Microbiol. 61 (2011) 487-492. doi:10.1099/ijs.0.022996-0.

[49] J. Sakpirom, D. Kantachote, T. Nunkaew, E. Khan, Characterizations of purple non-sulfur bacteria isolated from paddy fields, and identification of strains with potential for plant growth-promotion, greenhouse gas mitigation and heavy metal bioremediation, Res. Microbiol. 168 (2017) 266-275. doi:10.1016/j.resmic.2016.12.001.

[50] O. Fiehn, Metabolomics - the link between genotypes and phenotypes, Plant Mol. Biol. 48 (2002) 155-171. doi:10.1023/A:1013713905833.

[51] O. Fiehn, S.P. Putri, K. Saito, R.M. Salek, D.J. Creek, Metabolomics continues to expand: highlights from the 2015 metabolomics conference, Metabolomics. 11 (2015) 1036-1040. doi:10.1007/s11306-015-0846-z.

[52] T.R. Sana, J.C. Roark, X. Li, K. Waddell, S.M. Fischer, Molecular formula and METLIN personal metabolite Database matching applied to the identification of compounds generated by LC/TOF-MS, J. Biomol. Tech. JBT. 19 (2008) 258.

[53] L. Vaclavik, O. Lacina, J. Hajslova, J. Zweigenbaum, The use of high performance liquid chromatography-quadrupole time-of-flight mass spectrometry coupled to advanced data mining and chemometric tools for discrimination and classification of red wines according to their variety, Anal. Chim. Acta. 685 (2011) 45-51. doi:10.1016/j.aca.2010.11.018.

[54] H. Chen, P.C. Boutros, VennDiagram: a package for the generation of highly-customizable Venn and Euler diagrams in R, BMC Bioinformatics. 12 (2011) 35. doi:10.1186/1471-2105-1235.

[55] M.R. Seyedsayamdost, R.J. Case, R. Kolter, J. Clardy, The Jekyll-and-Hyde chemistry of Phaeobacter gallaeciensis, Nat. Chem. 3 (2011) 331-335. doi:10.1038/nchem.1002.

[56] E. Segev, T.P. Wyche, K.H. Kim, J. Petersen, C. Ellebrandt, H. Vlamakis, N. Barteneva, J.N. Paulson, L. Chai, J. Clardy, R. Kolter, Dynamic metabolic exchange governs a marine algalbacterial interaction, ELife. 5 (2016). doi:10.7554/eLife.17473.

[57] H. Mazur, A. Konop, R. Synak, Indole-3-acetic acid in the culture medium of two axenic green microalgae, J. Appl. Phycol. 13 (2001) 35-42. doi:10.1023/A:1008199409953.

[58] L. Labeeuw, J. Khey, A.R. Bramucci, H. Atwal, A.P. de la Mata, J. Harynuk, R.J. Case, Indole-3Acetic Acid Is Produced by Emiliania huxleyi Coccolith-bearing cells and triggers a physiological response in bald cells, Front. Microbiol. 7 (2016). doi:10.3389/fmicb.2016.00828.

[59] C. Paul, M.A. Mausz, G. Pohnert, A co-culturing/metabolomics approach to investigate chemically mediated interactions of planktonic organisms reveals influence of bacteria on diatom metabolism, Metabolomics. 9 (2013) 349-359. doi:10.1007/s11306-012-0453-1.

[60] C. Vidoudez, G. Pohnert, Comparative metabolomics of the diatom Skeletonema marinoi in different growth phases, Metabolomics. 8 (2012) 654-669. doi:10.1007/s11306-011-0356-6.

[61] M.M.W.B. Hendriks, F.A. van Eeuwijk, R.H. Jellema, J.A. Westerhuis, T.H. Reijmers, H.C.J. Hoefsloot, A.K. Smilde, Data-processing strategies for metabolomics studies, TrAC Trends Anal. Chem. 30 (2011) 1685-1698. doi:10.1016/j.trac.2011.04.019. 
1 Supplementary Figure 1

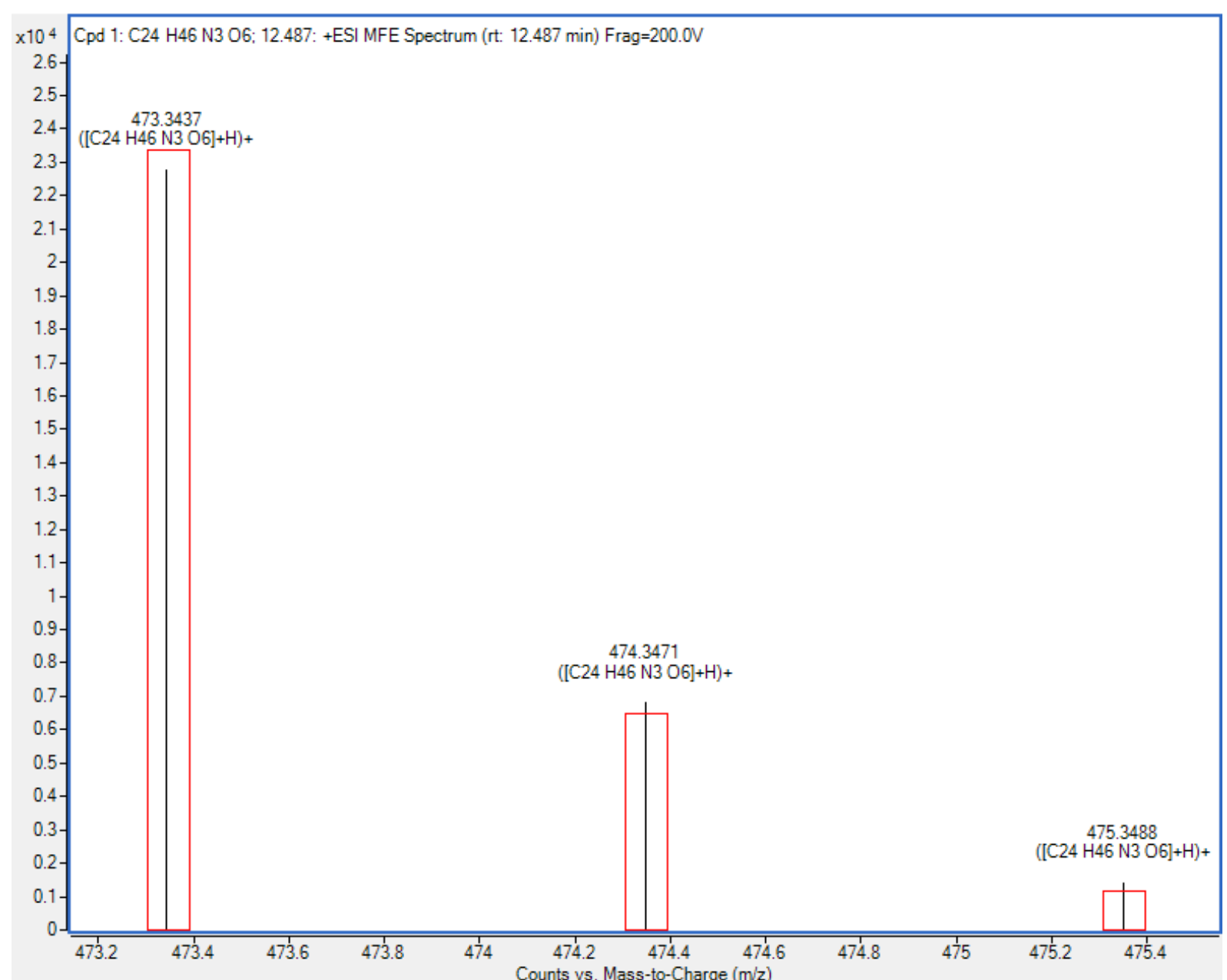


5 Supplementary Figure 2

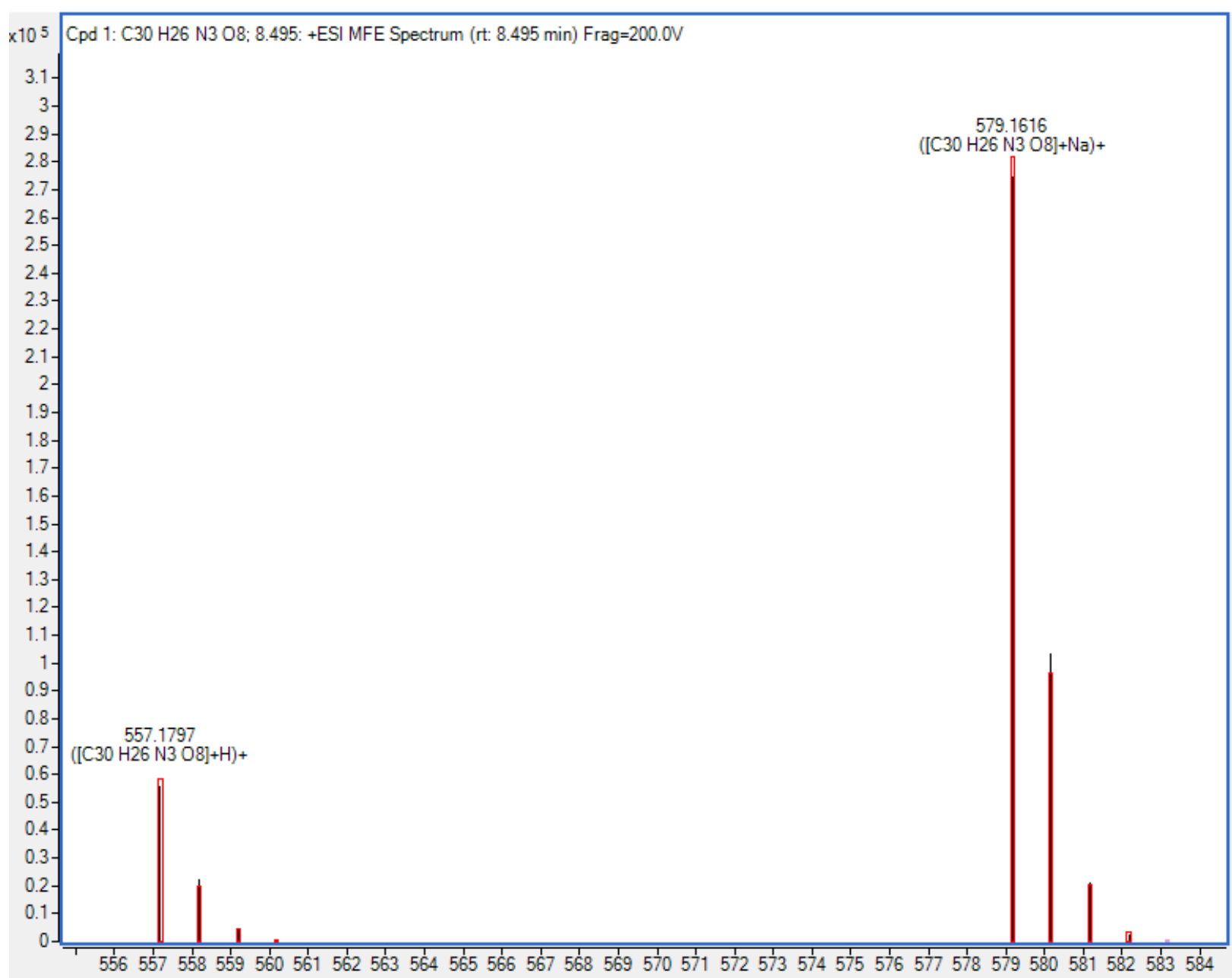
Counts vs. Mass-to-Charge (m/z) 
Supplementary Figure 3

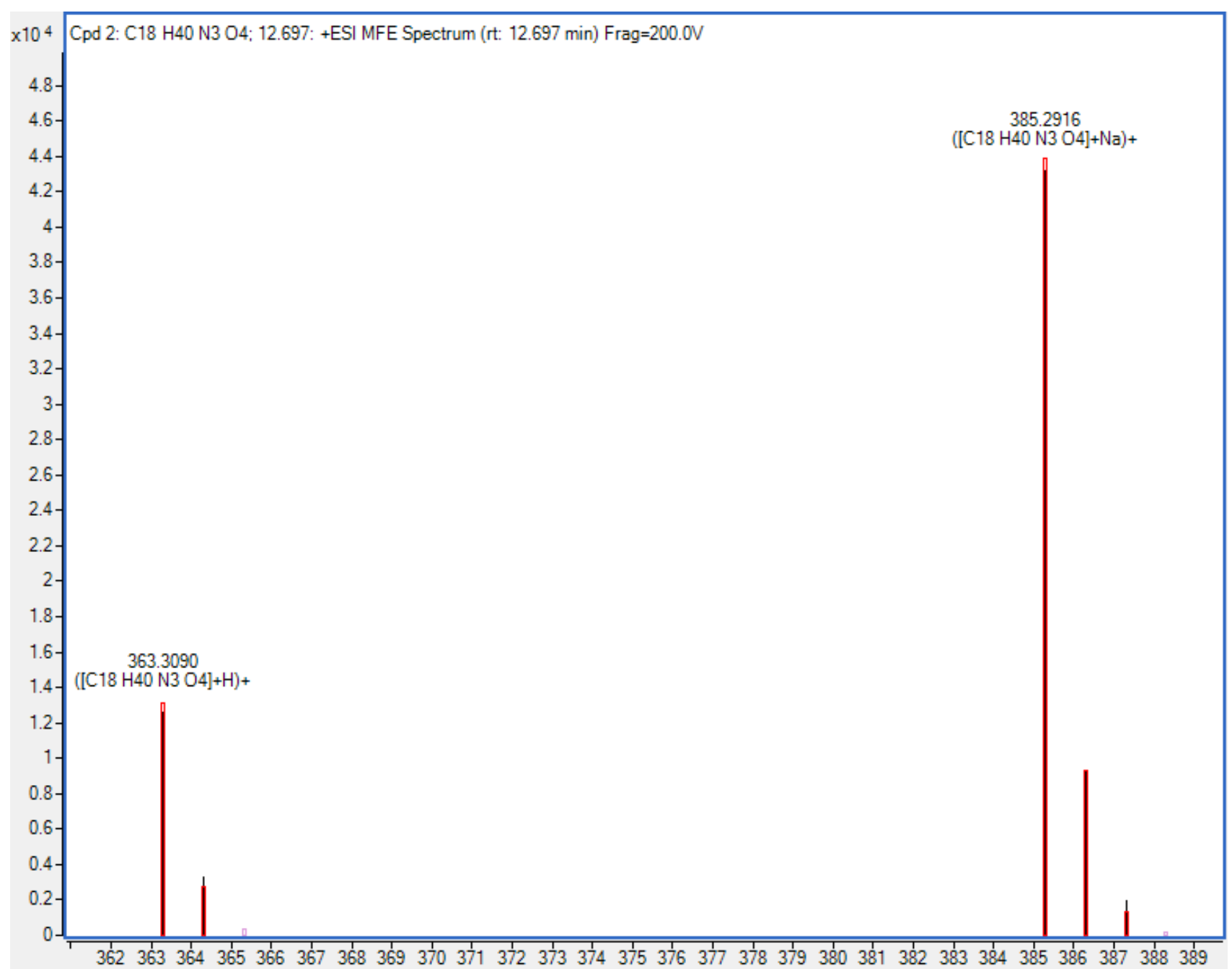


Supplementary Figure 4

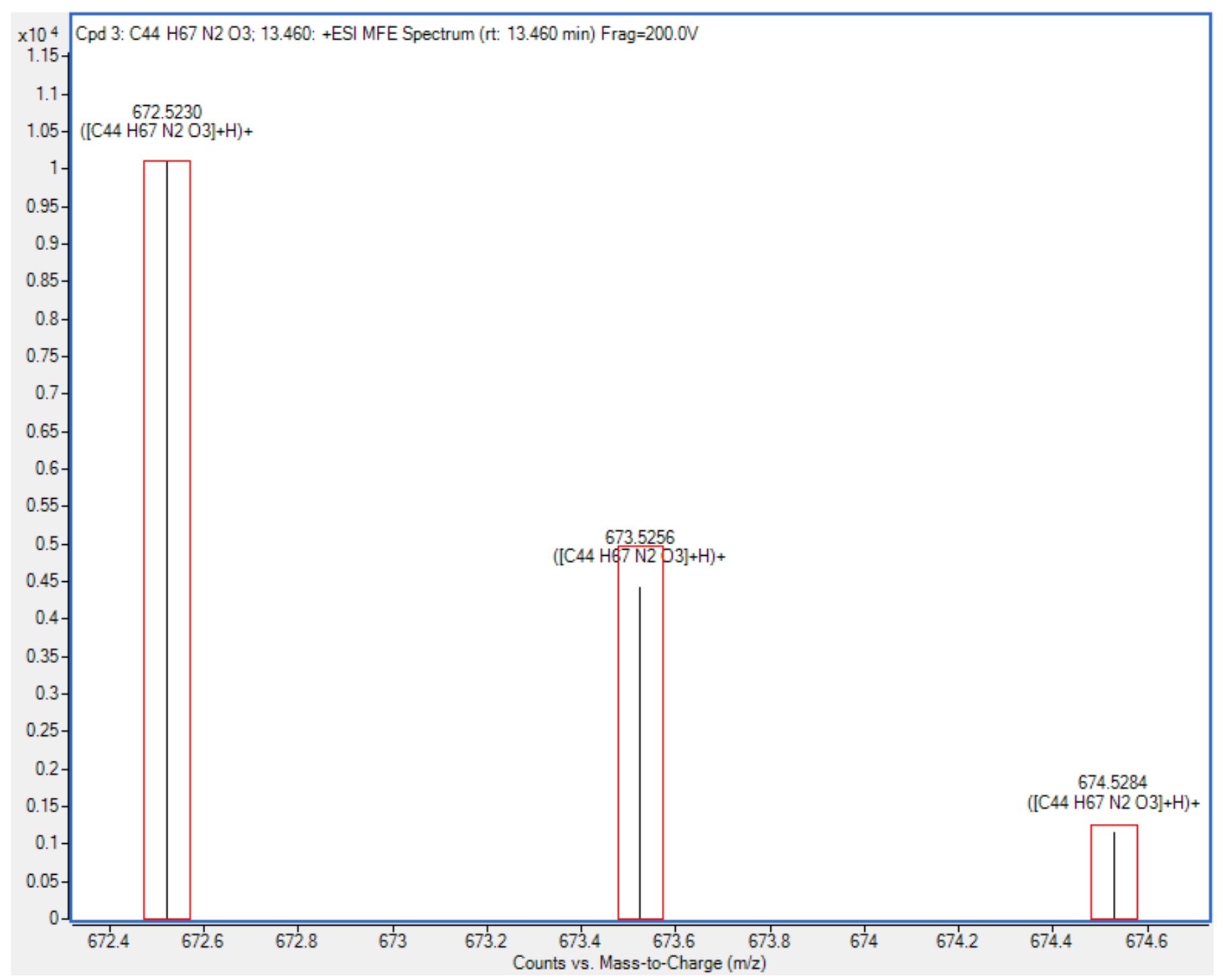

